\title{
Using disaster outcomes to validate components of social vulnerability to floods: flood damage and property damage across the USA
}

\author{
Beth Tellman ${ }^{1,2}$ \\ Cody Schank ${ }^{3}$ \\ Bessie Schwarz ${ }^{2}$ \\ Peter Howe ${ }^{5}$ \\ Alex de Sherbinin ${ }^{4}$ \\ ${ }^{1}$ Earth Institute, Columbia University, New York, NY \\ ${ }^{2}$ Cloud to Street, New York, NY \\ ${ }^{3}$ Dell EMC, Austin, TX \\ ${ }^{4}$ Center for International Earth Science Information Network (CIESIN), Columbia University, \\ New York, NY, \\ ${ }^{5}$ Department of Environment and Society, Utah State University
}

\begin{abstract}
:
Social vulnerability indicators seek to identify populations susceptible to hazards based on aggregated sociodemographic data. Vulnerability indices are rarely validated with disaster outcome data at broad spatial scales, making it difficult to develop effective national scale strategies to mitigate loss for vulnerable populations. This paper validates social vulnerability indicators using two flood outcomes: death and damage. Regression models identify sociodemographic factors explaining variation in outcomes from 11,629 non-coastal flood events in the USA (2008-2012), controlling for flood intensity using stream gauge data. We compare models with i) socioeconomic variables, ii) the composite social vulnerability index (SoVI), and iii) flood intensity variables only. The SoVI explains more variance in death (AIC = 2829) and damage $\left(R^{2}=0.125\right)$ than flood intensity alone (death-AIC $=2894$; damage- $\left.R^{2}=0.089\right)$, and models with individual sociodemographic factors perform best (death-AIC $=2696$; damage$\mathrm{R}^{2}=0.229$ ). Socioeconomic variables correlated with death (rural counties with a high proportion of elderly and young) differ from those related to property damage (rural counties with high percentage of both Black, Hispanic, and Native American populations in poverty). Future validation studies should examine other flood outcomes, such as evacuation, migration, and health, across scales.
\end{abstract}

Keywords: Social vulnerability, flooding, validation, USA, property damage, death

\section{Introduction}

\subsection{From Risk to Vulnerability}

Social vulnerability research has its contemporary origins in risk-hazard research focused on the exposure of people or places to environmental threats [1], demonstrating how various types of 
environmental or "natural" hazards differentially affect populations based on their underlying susceptibility to harm. The National Flood Insurance Program in the United States reflects the policy impacts of this research [2]. This significance notwithstanding, inadequate attention to the socio-economic conditions that predispose specific populations to greater exposure and consequences has led to various critiques of the risk-hazard approach [3]. New frameworks emerged that were focused on societal vulnerability to hazards and captured the root causes of exposure, sensitivity, and coping capacity to hazards [4,5]. These frameworks were ultimately enlarged to include the vulnerability of the environment or ecosystem in question and its impacts on exposed populations [6]. A simple definition emerging from this research is that vulnerability is the propensity for loss of lives, livelihood, or property when exposed to a hazard $[6,7]$.

Scientists studying the impacts, vulnerability and adaptation associated with climate change grew beyond the risk-hazards framework and began to focus on quantifying and understanding the relationships between hazards, exposure, sensitivity, and coping capacity [8-12]. Place based assessments of vulnerability provided insights into these relationships [13-16] but limited the ability to generalize understanding of vulnerability across wider geographies. Thus, efforts were made to quantify the social factors that predict the people and locations with a high propensity for loss of life, livelihood, and property from a hazard [17] in order to guide disaster management and climate change adaptation policy [11,12]. While efforts such as the Social Vulnerability Index (SoVI) have been formally adopted by government agencies [18] and vulnerability maps have been used in adaptation planning [19], until recently there has been insufficient attention to validation [20-22]. The predictive ability of social vulnerability indices remains largely untested, since few studies have examined how vulnerability indices relate to loss and damages or which socio-demographic factors are most predictive of harm [20,23]. This also means that the ability of policy makers to accurately target adaptation strategies that would reduce harm to populations most at risk may be limited precisely because the indicators and indices available may be inadequate for predicting the propensity for loss in a hazard. Validation of these widely used indices is particularly important to understand how factors of social vulnerability may remain constant or change over spatial, temporal, and socio-political scales as well as across different types of hazards [24]. Quantitative social vulnerability assessment requires more attention to internal validity through sensitivity and uncertainty analysis (e.g., Tate et al. [20]) and external validity through the comparison of disaster outcomes to vulnerability metrics (e.g., [21]. As climate-related hazards become more severe it is all the more important to assess the validity of vulnerability indicators and maps, which are increasingly used to target adaptation resources [22].

Vulnerability assessments increasingly analyze coping capacity, the ability of an individual or population to mobilize assets or entitlements to cope with loss or mitigate future harm from hazards [25-32]. Coping capacity is markedly difficult to measure over large geographic scales and among diverse populations because of data gaps and difficulties in quantifying the complexity of interactions among social structures, institutions and human agency. Metrics tend to capture this complexity inadequately, although a positive relationship between coping capacity and higher levels of education and investment in health has been proposed $[10,28,33]$. 
Research on resilience (sometimes defined as the ability to bounce back after a shock) has attempted to construct indices and quantitative assessments that include coping capacity $[34,35]$. These efforts, however, also lack empirical validation at large geographic scales. Overall, surprisingly few quantitative assessments of the specific factors leading to loss from hazards-or resilience to hazards-based on disaster outcomes exist [21]. Here we add to existing social vulnerability external validation studies of flooding $[21,36]$ by assessing two outcome measures - fatality and property damage-across the continental United States from 2008-2012 at the country scale, adopting the above referenced definition of vulnerability. This study represents a larger geospatial extent than previous studies, identifying social factors that transcend local place context that are related to loss and damage across the USA. We focus on riverine flooding and control for flood magnitude with stream gauge data to examine social factors leading to additional death and damage. The many other potential outcomes related to flooding, such health effects or long-term economic loss, remain a subject for future research.

\subsection{Measuring and validating social vulnerability to flood hazards}

Flood events affect more people globally than any other type of environmental hazard and are expected to increase in severity and frequency because of climate and demographic changes [37-40]. Flood vulnerability research has typically focused on hazard (the flood event) and exposure (population and livelihoods that could be impacted by the event). Exposure analyses as explored in the environmental sciences and engineering commonly rely on physically based hydrologic and hydraulic modeling to estimate the extent, depth, or frequency of flooding for a given storm event, and calculate the assets and population affected [41,42]. Both qualitative case studies $[43,44]$ and indicator approaches (e.g., the So $\mathrm{VI}^{1}$ or similar indices) [45-47] explore the differential impacts of floods on vulnerable people and places.

SoVI was developed by Cutter et al. [17] using a principal component analysis (PCA) on over 30 socio-demographic variables selected through literature review, which are primarily derived from US census data. PCA is a data reduction technique that uses an orthogonal transformation to convert a set of correlated variables into a new reduced set of uncorrelated variables, or components. The new components that represent a large proportion of variance in the data form the indicators for an additive social vulnerability index.

Social vulnerability is multi-faceted, and no one hazard outcome can serve as a comprehensive proxy for vulnerability validation. Social factors associated with flood vulnerability differ depending on whether the focus is on ex ante mitigation, immediate response, or longer term recovery from flood events [44]. Therefore, comprehensive validation of social vulnerability to floods requires assessing multiple outcomes and the social conditions related to each across three aforementioned phases of the disaster cycle. Death and property damage, the focus of this analysis, spans the mitigation and immediate aftermath phases of the disaster cycle, and here we review relevant and recent empirical social vulnerability literature. Death and property damage were chosen as the outcomes for analysis because of data availability for every county, 
allowing us to examine salient social vulnerability factors generalizable to the continental US. Outcomes of flood events related to social vulnerability not covered in this paper include outmigration, rate of return, property buyouts, health impacts not related to morality, and psychological impacts (see Rufat et al [44] for a review of these and other outcomes). We focus our review more on empirical US case studies, the study area for this paper.

\subsubsection{Flood fatality}

Social factors leading to fatalities to floods during the event (e.g. from drowning) and morbidity after the event (e.g. health complications- see [48]) differ in high-medium income versus low income countries [44,49]. In lower income countries females and those who are poor are at higher risk for flood fatality, often related to increased exposure by residing in the floodplain [49-51]. For example, more women than men drowned in the 1991 cyclone in Bangladesh, potentially due to women being homebound looking after children and valuables, traditional dress that restricts movements, or lower literacy rates [52]. In higher income countries, such as the USA, most fatalities during flood events are due to males drowning in vehicles [53-55]. Fatalities are more common in flash flood events, and in particular regions of the USA on the East Coast along Interstate 95, the Ohio River valley, and south-central Texas [53]. In the US, men exhibit riskier behavior than women in flood events, leading to high fatalities, in contrast to other hazard events in which women are generally more sensitive [54].

Common to all countries is increased risk of flood related death among the very young and very old [49,55-57]. The elderly are at risk of death because they may have difficulty evacuating or accessing medical services to treat heat, dehydration, stokes, or heart attacks [54]. Also common to all countries is higher risk of injury, death, and damage in floods and hurricanes for ethnic minorities or communities of color (as well as other disasters, see [58]). Hurricane Katrina, for example, disproportionately affected African-American communities in terms of flood fatality [59]. In Hurricane Katrina, mortality rates were up to 4 times higher for Blacks than Whites, particularly among elderly populations, suggesting an interaction between race and age [60]. Economic disadvantages, residential choices, and difficulty evacuating are all factors related to systemic and institutional racism that lead to higher fatality rates among minority populations [61]. Preparedness and mitigation investment by governments may also be systematically lower in communities of color, especially African-American communities [62], increasing their exposure and subsequent flood impacts.

Factors that reduce flood fatality include flood mitigation infrastructure [61,63], being in an urban area, and institutional investment in adaptation. Adaptation investments related to preparedness, early warning systems, and evacuation plans have effectively lowered property damage and death rates [63]. In all regions of the world (except Sub-Saharan Africa [64]), flood fatality rates have declined since 1980, especially for countries with the largest GDP growth who are hypothesized to be investing in additional adaptation and mitigation [65]. However, early warning systems are less common in rural areas and emergency services more dispersed, compared to urban areas [66,67]. Other studies have found rural areas of the US to be more vulnerable to flood fatalities [68]. 


\subsubsection{Property Damage}

Property damage represents one component of total economic loss in flood hazard events. Other longer term economic loss include job loss, crop damage, lost sales or closure of business $[69,70]$, costs of relocation or return, migration, and difficulty finding new work if displaced. Previous research identifying social factors leading to higher propensity for property damages include renter status, income, race, and poverty [71]. Research on property damage at the household level indicates lower socioeconomic status (e.g., poverty) is correlated with high damage rates because of lower building material quality and ability to withstand flood damage [72]. In the US, for example, unreinforced masonry buildings, which are more susceptible to flood damage [73], are a more common housing type among minority populations in the US [58]. Other studies indicate African-American populations are more likely to experience disproportionate flood damage due to location in floodplains where homes are cheaper, reduced access to investments in home protection infrastructure, and receive less protections from government built flood mitigation infrastructure $[58,62,74,75]$. Race may interact with poverty to affect economic damage. For example, in Hurricane Katrina, only low income African American populations had lower rates of returning and rebuilding, but not African American populations in general [76].

Research indicates locations with higher rental rates experience a higher propensity for property damage. One exception may be for mobile homeowners: $40 \%$ of all tornado deaths occur in mobile homes, but the relationship for floods has, to our knowledge, not been tested [71]. Homeowners have higher rates of purchasing insurance and investing in flood mitigation $[44,77]$, and therefore experience less damage $[55,78]$. Government programs for disaster assistance in the US, for example, privilege homeowners by design [79]. The relationship between purchasing insurance and race is unclear. One study in Georgia finds African-American populations over age 45 are more likely to purchase insurance [80] where other studies point to lower rates of insurance purchase by minorities [81].

Finally, rural areas are hypothesized to be more vulnerable to property loss as a share of total assets (e.g. normalized by total property value). Flood insurance for property owners is twice as common in urban as opposed to rural areas, for example [68]. Rural areas appear ${ }^{2}$ to have less flood-protective infrastructure (e.g., dams and levees) per capita compared to densely populated areas with high property values [82-84]. In this regard, it is noteworthy that the U.S. Federal Emergency Management Agency map modernization project, which updated and produced new flood maps for the U.S. from 2003-2008 (immediately prior to this study), focused on highly populated and urban areas [85]. Finally, in the US, development in

\footnotetext{
2 The National Dam Database, which contains this information, is not available for public download. However, derivative reports using the data in Texas and New Mexico describe more flood protection levees in urban areas. The visual maps appear to favor flood control structure in urban areas.
} 
floodplains has increased in rural areas, but decreased in urban areas from 1980-2016, implying increased flood exposure in rural areas of the country [86].

\subsection{Validating social vulnerability based on disaster outcomes}

Several quantitative flood vulnerability analyses combine exposure and sensitivity and include both biophysical and social variables $[45,54,61,87]$. Most quantitative assessments use social vulnerability indicators such as the SoVI that are generalized for all types of natural hazards [17], and which do not choose sociodemographic variables specific to flood hazards. In addition, minimal attention to the differential weighting of variables, analysis of uncertainty, and appropriate scales of analysis can lead to unstable results that predict different communities at risk when small changes in weights of specific variables are made $[20,24,88]$. Even more problematic, often social vulnerability indicators are not derived from empirical data on disaster loss specific to flood hazards [44].

We summarize relevant social vulnerability validation studies that use flood disaster outcomes in a regression (Table 1). We include studies reviewed for social vulnerability validation by Rufat et al [21], and an additional study they exclude [61]. We exclude from this table studies that analyze all hazards, or that use Pearson correlation or qualitative validation. Regression analyses, rather than two variable Pearson correlations, importantly estimate magnitude and direction of multiple effects while controlling for variation. To validate social vulnerability from flood hazard events, it is essential to control for event magnitude to assess the additional variance explained by social factors above and beyond hazard size. We report the geography extent, temporal extent, scale of analysis, sample size, flood hazard control variable, and main finding (statistically significant, with a + for positive correlation and - for negative) of previous validation studies (Table 1). 
Table 1. Summary of quantitative validation for social vulnerability to flood outcomes using correlation or OLS regression. Note SoVI is normalized on a z-score, and depending on the studies, positive SoVI scores may represent high or low social vulnerability. For simplification in this table we refer to positive SoVI scores as higher social vulnerability regardless of the numeric transformation employed in the paper. SVI= The Social Vulnerability Index from Flanagan et al [89]; SoVI= The Social Vulnerability Index [90]; CDRI=Community Disaster Resilience Index [91] RCl= Resilience Capacity Index [92].

\begin{tabular}{|c|c|c|c|c|c|c|}
\hline Study & $\begin{array}{l}\text { Geographic } \\
\text { Extent }\end{array}$ & $\begin{array}{l}\text { Temporal } \\
\text { Extent }\end{array}$ & Scale & $\mathbf{N}$ & $\begin{array}{l}\text { Hazard } \\
\text { control }\end{array}$ & Main finding \\
\hline $\begin{array}{l}\text { Rufat et al } \\
2019\end{array}$ & $\begin{array}{l}\text { New York and } \\
\text { New Jersey } \\
\text { affected } \\
\text { Sandy area }\end{array}$ & $\begin{array}{l}\text { One } \\
\text { hazard } \\
\text { (Sandy } \\
\text { 2012) }\end{array}$ & $\begin{array}{l}\text { Census } \\
\text { track }\end{array}$ & 3,947 & Flood depth & $\begin{array}{l}\text { FEMA Individual } \\
\text { Assistance: +SoVI } \\
\text { \% property loss: } \\
\text { +socioeconomic } \\
\text { status }\end{array}$ \\
\hline $\begin{array}{l}\text { Zahran et } \\
\text { al } 2008\end{array}$ & Texas & $\begin{array}{l}1997- \\
2001\end{array}$ & county & 832 & precipitation & $\begin{array}{l}\text { Fatality:+ social } \\
\text { vulnerability (defined } \\
\text { as high minority and } \\
\text { lower economic } \\
\text { status) }\end{array}$ \\
\hline $\begin{array}{l}\text { Finch et al } \\
2010\end{array}$ & New Orleans & $\begin{array}{l}\text { one } \\
\text { hazard } \\
\text { (Katrina } \\
\text { 2005) } \\
\end{array}$ & $\begin{array}{l}\text { census } \\
\text { tract }\end{array}$ & 181 & Flood Depth & $\begin{array}{l}\text { Rate of return to } \\
\text { home: -SoVI }\end{array}$ \\
\hline $\begin{array}{l}\text { Bakkensen } \\
\text { et al } \\
2017^{*}\end{array}$ & $\begin{array}{l}10 \text { states } \\
\text { (Southeastern } \\
\text { USA) }\end{array}$ & $\begin{array}{l}2000- \\
2012\end{array}$ & county & 41,916 & $\begin{array}{l}\mathrm{NCDC} \\
\text { magnitude }\end{array}$ & $\begin{array}{l}\text { Fatality: +SVI -CDRI, - } \\
\text { RCI } \\
\text { Damage: +SoVI, +SVI, } \\
\text {-CDRI, -RCI }\end{array}$ \\
\hline $\begin{array}{l}\text { Fekete et } \\
\text { al } 2009\end{array}$ & $\begin{array}{l}3 \text { regions } \\
\text { (River Elbe, } \\
\text { Mulde, and } \\
\text { Danube, } \\
\text { Germany) } \\
\end{array}$ & $\begin{array}{l}\text { one } \\
\text { hazard in } \\
2002\end{array}$ & $\begin{array}{l}\text { house- } \\
\text { hold }\end{array}$ & 1,697 & none & $\begin{array}{l}\text { Displacement:+urban, } \\
\text { +homeowner, +rooms } \\
\text { Shelter: +age, } \\
\text { +homeowner }\end{array}$ \\
\hline
\end{tabular}

*includes flash flood, hail, wind, strong wind, thunderstorm, tornadoes

Most previous attempts to validate components of social vulnerability based on hazard outcomes have been general to all hazards [16], based on one flood disaster or place $[21,46,47]$, use Pearson correlation [48,93] or are qualitative [94]. A few notable exceptions exist. Zahran et al (2008) analyzed over 800 flood events in Texas. Using precipitation and property damage data to control for flood magnitudes, they found two county-level demographic variables correlated to fatalities: high proportions of minorities and lower incomes. In other work, Finch et al. [47] found that high social vulnerability, when controlling for flood depth, predicts lower rate of residents returning home post-Katrina. Other single event flood studies $[21,46]$ validate social vulnerability metrics and other social factors against a variety of flood outcomes, including displacement rate, shelter, property loss, and FEMA assistance. The largest spatial and temporal validation study (across the southeastern USA, and 
the highest sample size, from Bakkensen et al [36] included 5 hazard types (including floods). They found the social vulnerability indices correlated with higher rates of property damage, but only one social vulnerability index (SVI- see [89] was positively correlated with fatality rates.

Quantitative validation of social vulnerability to hazards, and to flooding in particular, at large spatial scales remains elusive. One of the challenges is defining specific outcome variables that link to one or more of the components of vulnerability [95]. Possible outcome variables range from the immediate, such as fatalities and injuries, to the long term, such as economic recovery. Various outcome metrics, such as psychological wellbeing, are lacking in availability or difficult to derive from extant sources, such as demographic data. Data-poor areas of the world are even more challenging to assess, and prevent broad-scale regional or global comparisons.

Despite these challenges, it is imperative to develop methods based on extant data to test assumptions that certain social dimensions increase vulnerability to hazards such as floods [96]. Many researchers who develop social vulnerability indicators do so with the goal of drawing attention to the differential risks faced by those who are most disadvantaged $[97,98]$. Yet, without rigorous validation efforts, the development and use of such indicators risks being discredited owing to claims that they are unable to predict future harm $[22,99]$. The ability to understand and predict future risks is particularly important as discourse around loss and damage rises in the UN Framework Convention on Climate Change [100]. Recent social vulnerability validation studies call for more research to identify which social vulnerability models and factors consistently explain disaster outcomes, across hazards, outcomes, and spatial and temporal scales [44]. This paper contributes to this research by providing the broadest spatial scale validation of social vulnerability to flood hazards to date. We estimate the socio-economic dimensions of sensitivity to death and damage in floods over a large number of events ( $n=11,938$, all major flood events from 2008-2012) in the contiguous United States, controlling for hazard magnitude. Generalized linear regression models address four primary research questions at the US county scale:

1) Which demographic variables predict fatalities directly attributed to floods?

2) Which demographic variables predict flood damages?

3) Does a composite index of social vulnerability (SoVI) correlate with flood death and damage, when accounting for hazard intensity?

4) Which populations and their locations are most likely to experience death and damage in a large (500-year) future flood event?

\section{Materials and methods}

Our general approach to social vulnerability validation for floods was to regress flood outcome variables for which data available across the contiguous USA were available. Property damage 
and fatality and two outcomes which fit this criteria, and have been used in other vulnerability validation studies as dependent variables in regression [21,36,61,61]. Data analysis and methodological details are provided below.

\subsection{Data:}

\subsubsection{Property and fatality data}

Model response variables- fatality and property damage- are available through SHELDUS [101] version 14.1, downloaded in July $2016^{3}$. All flood outcome data were limited to flood events in the contiguous U.S. from 2008-2012, excluding coastal floods ( $n=11,938$ ). The years 2008-2012 were chosen because they represented the two years precluding and following the 2010 Census, and we assume social dynamics to be stationary for approximately the 5 years of this analysis. We used stream gauge data to control for hazard magnitude, effective for river and flash flooding. We excluded coastal floods from our analysis which would have required windspeed or storm surge to control for fatality and hazards, and storm surge data across the US is unavailable. Flood fatalities and damage are the only consistent flood event outcomes in SHELDUS, and which were available across the contiguous US at the time of this study.

Flood fatality data in SHELDUS are from the Storm Data publication provided by the National Centers for Environmental Information (NCEI, formerly the National Climatic Data Center), part of NOAA. Storm Data preparers from the National Weather Service report fatality information in total numbers per event (and usually per county). When the NCEI data report fatalities across several counties, SHELDUS splits the fatality data into each location reported. It is unclear how many fatalities are "direct" (e.g. drowning in water) vs. "indirect" (e.g. medical supplies at a home ran out due to flood preventing gathering supplies), but these descriptions are sometimes included the event narrative. A total of 247 non-coastal flood fatality events (an event for which at least one death occurred), and a total of 335 deaths, occurred between 2008-2012, 238 of which had event descriptions. The quality of these data are subject to NWS reporting, but it is considered the best officially verified and highest quality dataset for significant weather phenomena in the United States ${ }^{4}$. Undercounts of fatalities or missing records from small events could result in biases in this dataset due to resource constraints in reporting.

For cross validation and for interpretation of regression models, we text-mined the 238 flood fatality events, for select causes and variables based on the limited descriptions. After reading event narratives, we mined the text for trends in age, gender, and cause of death. For gender of the fatalities, the words "woman," "girl," "mother" or "lady" were used to determine if there was a female involved in the fatality; "man," "boy," "son," and "father" were used to determine

\footnotetext{
${ }^{3}$ More recent versions of these data are now available through the Center for Emergency Management and Homeland Security at Arizona State University: https://cemhs.asu.edu/node/7 ${ }^{4}$ https://www.ncdc.noaa.gov/stormevents/faq.jsp
} 
if a male was involved; "child," "baby," "daughter," "son," "boy," and "girl" were used to determine if there was a young person involved; "elderly" or "senior" were used to determine if there was an elderly person involved; "mobile" and "RV" were used to search to mobile home deaths; "truck," "car," and "vehicle" were used to determine if a car was involved; and "drown*" (to cover "drown," "drowned," and "drowning") were used to search for drowning fatalities. Note that not all event narratives have words that indicate gender, age or cause of death, so this represents patterns in types and causes of death and not a comprehensive characterization. The number of cases with presence or absence of each word were added and used to calculate the percentage of cases where these words appeared to gain a sense of demographic factors in the fatality descriptions.

We analyzed property damage data from SHELDUS, reported at the county scale $(n=11,245$ events with damage data). A total of USD24 billion in losses were recorded in total, with a mean of USD2.06 million in damage per event per county, and a median of USD200,000. Unlike fatality data, where the NCEI data report deaths across several counties, SHELDUS splits the damage data equally across each county affected. These data have a large uncertainty and are characterized as "guesstimates" in the SHELDUS metadata. Property damage data was greater than 0 for almost all flood events; only 408 had a value of " 0 ." Storm data preparers reporting to NOAA might use USGS, US Army Corps of Engineers, newspaper, utility companies, insurance adjuster data, or other information to estimate monetary damage. Damage includes both private property and public infrastructure. Crop damage amounts are reported separately and are not used in this analysis. Property damage data have been used in vulnerability validation assessments [36]. Other analyses have shown inaccuracies in these data, however, in particular, that small or moderate damage is often underreported, and counties vary in what they count as "damage" leading to inaccuracies of up to $40 \%$ in estimates [102]. These issues notwithstanding, they remain the best publicly available property damage estimate dataset at a country scale. Recent studies have obtained insurance adjustment data from FEMA, which likely provide improved private household loss estimates, but those data are not publicly available [103]. We considered using the FEMA Public Assistance data [104] federally declared disaster events $(n=351)$. These property damage estimates are considered to be of higher quality, and have been used in other vulnerability validation studies [21]. However, due to its much smaller sample size, it was not used in this analysis. We normalized property damages by the estimated total housing value in each county in the 2010 US Census. Our normalization approach is similar to studies which have used the ratio of property losses to total value [21] or added a capital stock variable (multiplying income times population) as a control in regression [36]. We recognize the limits of using property data to validate economic outcomes of flood hazards, because it only represents direct loss and not long-term business and employment loss, but these estimates are unfortunately unavailable.

\subsubsection{Flood hazard magnitude and built environment data}

We accounted for hazard intensity by using USGS stream gauge data [105] to calculate the flood return time of each storm event. The NCEI dataset reports a latitude and longitude location of each event either by the Storm Data preparer entering in the latitude and longitude directly, or by NCEI calculations from a reported location, distance, and 16-point compass 
direction (e.g. 5 miles ESE Atlanta). It was difficult to know which stream gauge best represented the hazard intensity, especially given uncertainty in event coordinates. Our strategy to connect events to relevant stream gauges was to match event coordinates to the USGS Watershed Boundary Dataset using HUC (Hydrologic Unit Maps) levels 4, 6, 8, 10, and 12. Each HUC level is a different size watershed at nested levels of spatial aggregation; level 12 watersheds are small subwatersheds (the smallest size we used), 10 digit are watersheds, 8 digit are subbasin, and 6 digit are basins, and 4 digit are subregions (largest size we used). We then selected all stream gauges in all HUCs that overlapped the storm event point, and gathered all stream gauge readings in between the start and end of the flood event as reported by SHELDUS. We selected the maximum instantaneous discharge reading across all HUC levels and days during the event. We assume the maximum discharge represents peak hazard intensity and would provide the best control for the regression. In order to compare hazard intensity for different events, discharge was converted into flood return times using USGS Stream Stats [106]. This method interpolates discharge data using a log-linear model to develop a continuous curve. We matched the flood event discharge data to its location on the Stream Stats curve to estimate the flood return period of the storm event.

We included data on impervious surface, which has been found to increase property damage for flood events [107]. We controlled for built environment by including percent developed impervious surface by county from the National Land Cover Dataset (NLCD) for 2011 [108].

\subsubsection{Social vulnerability data}

Predictor variables are available through the U.S. Decennial Census (2010) and the American Community Survey (ACS). We used all 29 individual predictor variables used in the 2006-2010 version of the Social Vulnerability Index (SOVI) (Cutter et al. 2003), plus two additional variable consistent with the literature that increased propensity for fatalities or damages during a flood event (percent rural [68] and interactions of race and class [76]) (Table 2). The SoVI indicator was purchased from the University of South Carolina for the 2006-2010 version for the county scale [101]. The spatial unit of analysis is the county or county-equivalent. Broad-scale geographic effects were controlled for by including U.S. Census regional and division designations as dummy variables for models. All continuous variables, including property damage, social factors, impervious surface, and hazard intensity data were converted to Zscores with a mean of zero and standard deviation of one. 
Table 2: Social variables used in the analysis, description, rationale (from Cutter et al 2003, unless otherwise specified with ${ }^{*}$ ), hypothesized relationship ( $+F$ for increase in fatalities, $-F$ for decrease in fatalities, $+D$ for increase in damage, $-D$ for decrease in damage), and the data source (DC= decennial census).

\begin{tabular}{|c|c|c|c|c|c|}
\hline Variable & Description & Rationale & $\begin{array}{l}\text { Hypothesized } \\
\text { Relationship }\end{array}$ & Source & $\begin{array}{l}\text { Census } \\
\text { Group or } \\
\text { Table }\end{array}$ \\
\hline totalPopulation & Total population & $\begin{array}{l}\text { To offset fatality models } \\
\text { (control for highly populated } \\
\text { areas)* }\end{array}$ & $+\mathrm{F}$ & 2010 DC & P3 \\
\hline \%Black & Percent of population Black & \multirow{4}{*}{$\begin{array}{l}\text { Residential locations in high } \\
\text { hazard areas }\end{array}$} & $+\mathrm{F},+\mathrm{D}$ & 2010 DC & $\mathrm{P} 2$ \\
\hline \%NativeAmerican & $\begin{array}{l}\text { Percent of population Native } \\
\text { American }\end{array}$ & & $+\mathrm{F},+\mathrm{D}$ & 2010 DC & P3 \\
\hline \%Asian & Percent of population Asian & & $+\mathrm{F},+\mathrm{D}$ & 2010 DC & P3 \\
\hline \%Hispanic & Percent of population Hispanic & & $+F,+D$ & 2010 DC & P4 \\
\hline \%Female & Percent of population female & \multirow{3}{*}{$\begin{array}{l}\text { Lower wages, family care } \\
\text { responsibilities can increase } \\
\text { vulnerability, but men more } \\
\text { likely to die in floods }\end{array}$} & $-F$ & 2010 DC & P12 \\
\hline \%FemaleCivilianWorkforce & $\begin{array}{l}\text { Percent of women who are } \\
\text { working }\end{array}$ & & $+\mathrm{D}$ & $\begin{array}{l}2010 \text { 5-year } \\
\text { ACS }\end{array}$ & B23001 \\
\hline \%FemaleHeadOfHouse & $\begin{array}{l}\text { Percent households headed by } \\
\text { females }\end{array}$ & & $+\mathrm{F},+\mathrm{D}$ & 2010 DC & P18 \\
\hline \%Under5yo & Percent population under 5 & $\begin{array}{l}\text { Higher potential for fatalities- } \\
\text { drowning }\end{array}$ & $+\mathrm{F}$ & $2010 \mathrm{DC}$ & P12 \\
\hline \%Over65yo & Percent population over 65 & \multirow{2}{*}{$\begin{array}{l}\text { Difficulty evacuating due to } \\
\text { mobility constraints }\end{array}$} & $+\mathrm{F}$ & $2010 \mathrm{DC}$ & P12 \\
\hline \%NursingHome & $\begin{array}{l}\text { Percent population in nursing } \\
\text { home }\end{array}$ & & $+\mathrm{F}$ & $2010 \mathrm{DC}$ & P42 \\
\hline \%NoEnglish & $\begin{array}{l}\text { Percent of population with } \\
\text { household has a limited English } \\
\text { speaking status }\end{array}$ & $\begin{array}{l}\text { Difficulty communicating for } \\
\text { evacuation* }\end{array}$ & $+\mathrm{F}$ & $\begin{array}{l}2010 \text { 5-year } \\
\text { ACS }\end{array}$ & B16002 \\
\hline perCapitalncome & $\begin{array}{l}\text { Per capital income in past } 12 \\
\text { months }\end{array}$ & $\begin{array}{l}\text { Lower incomes indicate } \\
\text { poverty }\end{array}$ & $+\mathrm{D}$ & $\begin{array}{l}2010 \text { 5-year } \\
\text { ACS }\end{array}$ & B19301 \\
\hline \%RenterOcc & $\begin{array}{l}\text { Percent population in rental } \\
\text { homes }\end{array}$ & $\begin{array}{l}\text { Less invested in flood } \\
\text { mitigation to prevent damage }\end{array}$ & $+\mathrm{D}$ & 2010 DC & $\mathrm{H} 4$ \\
\hline \%Unoccupied & Percent of houses un occupied & \multirow{5}{*}{$\begin{array}{l}\text { Value, quality, of housing } \\
\text { stock may indicate } \\
\text { "economic health" of a } \\
\text { community, over crowded } \\
\text { and vacant housing may be } \\
\text { likely to experience more } \\
\text { damage }\end{array}$} & $+\mathrm{D}$ & $2010 \mathrm{DC}$ & $\mathrm{H} 3$ \\
\hline medianHouseValue & $\begin{array}{l}\text { Median value of owner occupied } \\
\text { housing (USD) }\end{array}$ & & $-D$ & $\begin{array}{l}2010 \text { 5-year } \\
\text { ACS }\end{array}$ & B25077 \\
\hline medianRent & $\begin{array}{l}\text { Median value of renter occupied } \\
\text { housing (USD) }\end{array}$ & & $-D$ & $\begin{array}{l}2010 \text { 5-year } \\
\text { ACS }\end{array}$ & B25064 \\
\hline \%MobileHomes & $\begin{array}{l}\text { Percent of population living in } \\
\text { mobile homes }\end{array}$ & & $+\mathrm{D},+\mathrm{F}$ & $\begin{array}{l}2010 \text { 5-year } \\
\text { ACS }\end{array}$ & B25024 \\
\hline peoplePerUnit & Number of people per room & & $+\mathrm{D}$ & $\begin{array}{l}2010 \text { 5-year } \\
\text { ACS }\end{array}$ & B25014 \\
\hline totalHouseValue & $\begin{array}{l}\text { Calculated by summing number } \\
\text { of homes in each value category, } \\
\text { and adding total value }\end{array}$ & $\begin{array}{l}\text { Used to normalize property } \\
\text { damage data* }\end{array}$ & $+\mathrm{D}$ & $\begin{array}{l}2010 \text { 5-year } \\
\text { ACS }\end{array}$ & B25075 \\
\hline$\%$ NoCar & Percent of homes with no vehicle & $\begin{array}{l}\text { Could be easier to evacuate, } \\
\text { also an indicator of relative } \\
\text { less poverty }\end{array}$ & $+\mathrm{F}$ & $\begin{array}{l}2010 \text { 5-year } \\
\text { ACS }\end{array}$ & B25044 \\
\hline \%UnderPoverty & $\begin{array}{l}\text { Percent of population living in } \\
\text { poverty, defined threshold varies } \\
\text { by age, household, and number } \\
\text { of children }\end{array}$ & \multirow{2}{*}{$\begin{array}{l}\text { Related to ability to absorb } \\
\text { losses and invest in resilience } \\
\text { to hazard impacts, access } \\
\text { insurance, and other } \\
\text { programs }\end{array}$} & $+\mathrm{D}$ & $\begin{array}{l}2010 \text { 5-year } \\
\text { ACS }\end{array}$ & C17002 \\
\hline \%Households200k & $\begin{array}{l}\text { Percent of households making at } \\
\text { least } \$ 200,000 \text { USD in join } \\
\text { income in past year }\end{array}$ & & $-D$ & $\begin{array}{l}2010 \text { 5-year } \\
\text { ACS }\end{array}$ & B19001 \\
\hline $\begin{array}{l}\text { \%LessThan12yearsEducati } \\
\text { on }\end{array}$ & $\begin{array}{l}\text { Percent of population who have } \\
\text { not completed } 12^{\text {th }} \text { grade } \\
\text { (highschool) }\end{array}$ & $\begin{array}{l}\text { Low education constrain } \\
\text { ability to understanding } \\
\text { warning information }\end{array}$ & $+\mathrm{F}$ & $\begin{array}{l}2010 \text { 5-year } \\
\text { ACS }\end{array}$ & B15002 \\
\hline
\end{tabular}




\begin{tabular}{|c|c|c|c|c|c|}
\hline \%NoHealthInsurance & $\begin{array}{l}\text { Percent of population with no } \\
\text { health insurance }\end{array}$ & \multirow{3}{*}{$\begin{array}{l}\text { Hospitals, ability to access } \\
\text { care due to mobility } \\
\text { constraints, and due to } \\
\text { health insurance could affect } \\
\text { disaster impacts }\end{array}$} & $+\mathrm{F}$ & $\begin{array}{l}2010 \text { 5-year } \\
\text { ACS }\end{array}$ & B27001 \\
\hline \%AmbulatoryDifficulty & $\begin{array}{l}\text { Percent of population with } \\
\text { mobility constraints }\end{array}$ & & $+\mathrm{F}$ & $\begin{array}{l}2013 \text { 5-year } \\
\text { ACS }\end{array}$ & B18105 \\
\hline HOSTPTC & $\begin{array}{l}\text { Per capita number of community } \\
\text { hospitals }\end{array}$ & & $+\mathrm{F}$ & SOVI variables & \\
\hline \%SocialSecurity & $\begin{array}{l}\text { Percent population with social } \\
\text { security income }\end{array}$ & $\begin{array}{l}\text { Social dependence indicates } \\
\text { economic marginalization } \\
\text { requiring extra support }\end{array}$ & $\begin{array}{l}\text { +long term D } \\
\text { (not property) }\end{array}$ & $\begin{array}{l}2010 \text { 5-year } \\
\text { ACS }\end{array}$ & B19055 \\
\hline \%EmployedInServices & $\begin{array}{l}\text { Percent population employed in } \\
\text { services including healthcare } \\
\text { support, fire fighting, policing, } \\
\text { food preparing, and maintenance }\end{array}$ & $\begin{array}{l}\text { Occupations that could be } \\
\text { affected by hazard event (e.g } \\
\text { jobs that may not return post } \\
\text { disaster) }\end{array}$ & $\begin{array}{l}\text { +long term D } \\
\text { (not property) }\end{array}$ & $\begin{array}{l}2010 \text { 5-year } \\
\text { ACS }\end{array}$ & C24010 \\
\hline \%EmployedInExtractive & $\begin{array}{l}\text { Percent population employed in } \\
\text { mining, quarrying, or gas } \\
\text { extraction, forestry }\end{array}$ & & $\begin{array}{l}\text { +long term D } \\
\text { (not property) }\end{array}$ & $\begin{array}{l}2010 \text { 5-year } \\
\text { ACS }\end{array}$ & C24030 \\
\hline \%CivilianUnemployed & $\begin{array}{l}\text { Percent population unemployed } \\
\text { in labor force }\end{array}$ & $\begin{array}{l}\text { Less economic capacity to } \\
\text { invest in resilience }\end{array}$ & $+\mathrm{D}$ & $\begin{array}{l}2010 \text { 5-year } \\
\text { ACS }\end{array}$ & B23001 \\
\hline \%Family & $\begin{array}{l}\text { Percent of families where both } \\
\text { parents are present }\end{array}$ & $\begin{array}{l}\text { Potential for dual incomes or } \\
\text { house labor may increase } \\
\text { ability to invest in flood } \\
\text { mitigation }\end{array}$ & $-D$ & 2010 DC & P19 \\
\hline \%Rural & $\begin{array}{l}\text { Rural population/total population } \\
\text { per country }\end{array}$ & $\begin{array}{l}\text { Ruralness related to flood } \\
\text { fatalities due to access issues, } \\
\text { less flood mitigation } \\
\text { investment* }\end{array}$ & $+\mathrm{D},+\mathrm{F}$ & $2010 \mathrm{DC}$ & $\begin{array}{l}\text { (P002001/ } \\
\text { P002005) } \\
\text { in P2 }\end{array}$ \\
\hline SoVI & $\begin{array}{l}\text { 2006-2010 Social Vulnerability } \\
\text { Index }\end{array}$ & $\begin{array}{l}\text { Hypothesized link to } \\
\text { propensity for loss in hazards }\end{array}$ & $+\mathrm{D},+\mathrm{F}$ & $\begin{array}{l}\text { University } \\
\text { South Carolina }\end{array}$ & NA \\
\hline Race-poverty & $\begin{array}{l}\text { Multiplying \%Black, Hispanic, } \\
\text { Asian, and Native American with } \\
\text { poverty }\end{array}$ & $\begin{array}{l}\text { Intersectional race and } \\
\text { poverty lead to outsized } \\
\text { hazard impacts, not race } \\
\text { alone (Elliot and Pais 2006) }\end{array}$ & $+\mathrm{D}$ & $\begin{array}{l}2010 \text { DC and } \\
2010 \text { ACS }\end{array}$ & $\begin{array}{l}\mathrm{P} 2,3,4 \\
\text { and } \\
\mathrm{C} 170002\end{array}$ \\
\hline
\end{tabular}

\subsection{Regression Models}

We used regressions on fatality and property damage to test which individual socioeconomic factors, the SoVI index, biophysical factors (flood intensity and impervious surface) significantly influenced each outcome. The model of fatalities treated fatalities per event per county as count data, and we controlled for exposure (in this case, larger populations that would increase the likelihood one person would die) with an offset (logged population of each county). We used generalized linear models with a negative binomial distribution because fatality data have a mass point at 0 , and the variance is higher than the mean. We used the Pearson Chi-squared dispersion test and found over dispersion using a Poisson distribution (using the msme package- [109]). We use a zero-inflated model (eq. 1) because there may be one process that predicts if a fatality occurs (e.g., flood hazard intensity above a certain threshold) and a second process that predicts the number of fatalities (j), if a fatality does occur (e.g., social vulnerability factors). Zero-inflated models were implemented with R packages 'MASS' [110], 'pscl' [111], and 'Ime4' [112].

$$
\text { eq. } 1 \operatorname{Pr}\left(y_{i t}=j\right)=\left\{\begin{array}{c}
\pi_{i}+\left(1-\pi_{i}\right) g\left(y_{i t}=0\right) \text { if } j=0 \\
\left(1-\pi_{i}\right) g\left(y_{i t}\right) \text { if } j>0
\end{array}\right.
$$

$y_{i}=$ the dependent variable (fatalities) per spatial unit $(i)$, counties for each event $(t)$ 
$\pi_{i}=$ logistic link function, $\frac{\lambda_{i}}{1+\lambda_{i}}$

$g=$ the negative binomial distribution

$\lambda_{i}=\exp \left(\beta^{\prime} x_{i}+\beta^{\prime} x_{t}\right)$

$\beta^{\prime} x_{i}=$ coefficients for the time invariant independent variables for each county, $i$,

$\beta^{\prime} x_{t}=$ coefficients for the time varying independent variables for each event, $t$, such as hazard intensity or presence of a flash flood

For property models we used an OLS regression as specified in equation 2 .

$$
\text { eq. } 2 Y_{i}=\alpha+B_{1} x_{t}+B_{1} x_{i} \ldots B_{n} x_{i} \ldots+\varepsilon_{i t}
$$

$\alpha$ is the intercept

$B_{n} x_{i}$ is the coefficient for each independent variable for each county $i$.

$B_{n} x_{t}$ is the coefficients for time varying independent variables for each event, $t$, such as hazard intensity or presence of a flash flood

$\varepsilon_{i t}$ is the error term for each event $(t)$ per county $(i)$;

AIC is used to compare model fits [113] for fatality models, and $\mathrm{R}^{2}$ was used to compare model fit for property models. Percent deviance explained [114] compares deviance of null models (models with only the intercept) and models that include biophysical, sociodemographic, or social vulnerability indices. We used percent deviance explained for zero-inflated models and $\mathrm{R}^{2}$ for property damage models to compare the contribution of social factors predicting death and damage above and beyond biophysical factors. We tested for spatial autocorrelation (for both the mean and maximum residuals per county, since there are multiple observations for many counties) for both property and damage models using Moran's I from the spdep package (version 1.1-3, [115]).

\subsection{Variable selection and model construction}

Our approach differs from previous flood studies, which regress disaster outcomes on constructed social vulnerability indices or combined components of socioeconomic data (e.g. expert weighting, principal component analysis, or other statistical transformations termed "vulnerability profiles". Social vulnerability indices are very sensitive to weighting or combination schemes [116]. Therefore, we take a different approach, and examine individual socioeconomic components of vulnerability to identify which significantly predict hazard outcomes. The aim of our model strategy to was to identify social factors that systematically increase property damage or fatalities across the USA. We compare models constructed using theory (e.g. including variables identified from the literature, discussed above) versus data mining (e.g. machine learning) to identify factors increasing death and damage. We used a machine learning generalized boosted regression (Gbm) [117] algorithm to estimate relative importance of social variables from Table 2 to death and damage events respectively. We 
added dummy variables at both regional and division census levels to control for geographic differences in fatality and flood outcomes. We ensured no models included variables that were significantly correlated (>.55) to prevent multicollinearity, and also calculated variable inflation coefficients (VIF) to ensure no VIF was >5 [118].

We constructed six types of models to answer our research questions (Table 3). Model 1 is the null model of fatality and property damage. Model 2 contains only the biophysical variables of flood return time, impervious surface, and flash floods, while model 3 adds the SoVI index, and both are regressed against both flood fatalities and property damage. Models $4 a, 4 b$, and $4 c$ were theoretically informed models to predict fatalities controlling for hazard intensity (4a), regional effects (4b), and division effects (4c). Social factors theoretically predicting death include gender, percent Black, percent rural, age $(\%<5$ and $>\% 65)$, mobile homes, poverty, owning a car, factors that could make heeding early warning difficult (difficulty understanding English, ambulatory difficulty, low education), and health (hospitals, health insurance). Social factors theoretically predicting damage include people of color (\%Black, \%Native American, \%Hispanic, \%Asian), housing stock and ownership (mobile homes, renters, people per unit, vacancies and median house value ${ }^{5}$ ), and poverty (correlated with per capital income, which was discarded). Female heads of house theoretically are vulnerable to more flood damage, but this variable was correlated with \%Black, so it was not included. Percent impervious is also not included in social models, as it is significantly correlated with percent rural $(r=-.54, p<.001$, Pearson Correlation). Models $6 \mathrm{a}, 6 \mathrm{~b}, 6 \mathrm{c}$, and $6 \mathrm{~d}$ were theoretically informed models to predict property damage, controlling for hazard intensity (6a), regional effects (6b), division effects $(6 c)$, and interacting race and class (6d). Models $5 a, 5 b$, and $5 c$ includes variables identified through machine learning to predict fatalities as count data (5a), fatalities as binary (5b), and property damage.

Table 3. Fatality and Property damage validation models

\begin{tabular}{|c|c|c|c|}
\hline $\begin{array}{l}\text { Model } \\
\#\end{array}$ & Rationale & Independent Variables & Dependent Variables \\
\hline 2 & Biophysical Variables & floodReturnTime $+\%$ Impervious+ flashflood $* *$ & \multirow{5}{*}{ Fatality, Damage } \\
\hline 3 & SoVI Index, controlling for hazard intensity & US_SOVI+ floodReturnTime+ \%impervious+ flashFlood & \\
\hline $4 a$ & Social factors identified in literature & $\begin{array}{l}\text { floodReturnTime + flashFlood + \%Rural + \%MobileHomes + } \\
\text { \%UnderPoverty + \%Under5yo + \%Over65yo + \%NoEnglish + } \\
\text { \%AmbulatoryDifficulty+ \%NoHealthInsurance+ HOSPTPC } \\
\text { +\%LessThan12yearsEducation+ \%NoCar }\end{array}$ & \\
\hline $4 \mathrm{~b}$ & $\begin{array}{l}\text { Social factors identified in literature + } \\
\text { regional variation }\end{array}$ & $\begin{array}{l}\text { floodReturnTime + flashFlood + \%Rural + \%MobileHomes + } \\
\text { \%UnderPoverty + \%Under5yo + \%Over65yo + \%NoEnglish + } \\
\text { \%AmbulatoryDifficulty + \%NoHealthInsurance+ } \\
\text { \%LessThan12yearsEducation + HOSPTPC + \%NoCar + regions }\end{array}$ & \\
\hline 4c & $\begin{array}{l}\text { Social factors identified in literature + } \\
\text { divisional variation }\end{array}$ & $\begin{array}{l}\text { floodReturnTime + flashFlood + \%Rural + \%MobileHomes + } \\
\text { \%UnderPoverty + \%Under5yo + \%Over65yo + \%NoEnglish + } \\
\text { \%AmbulatoryDifficulty +\%NoHealthInsurance+ } \\
\text { \%LessThan12yearsEducation + HOSPTPC + \%NoCar +divisions }\end{array}$ & \\
\hline
\end{tabular}

${ }^{5}$ Correlated with households making over $200 \mathrm{k}$, median rent, and per capital income, variables which we excluded 


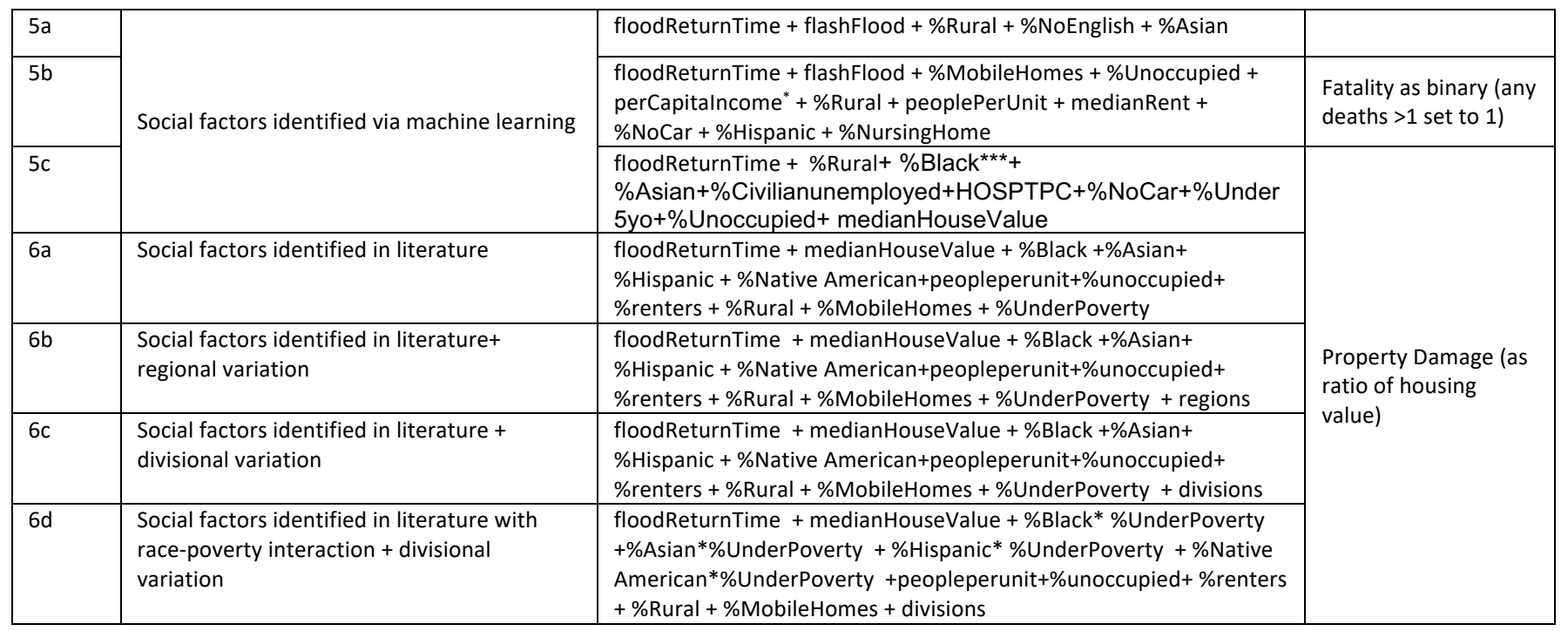

*correlated with households200k, excluded from model

**flash flood only included in fatality models (tied to death in literature, but not property loss)

$* * *$ correlated with \%FemaleHeadofHouse

\subsection{Predictive Maps}

Our final research question aims to identify which counties are most vulnerable to flood fatalities and damage for a large event. We use the best fitting models (based on AIC or $\mathrm{R}^{2}$ ) to predict the number of fatalities and property damage ratio for a large flood event. In these models, we set the population in each county equal to 100,000, and assume a flood return time of 500 years, which is the largest flood time we can estimate using the Stream Stats model. The top ten counties for predicted fatalities and property damage are listed (Table 7), and the rates predicted for the top ten most populous counties (Table 7). A bivariate choropleth map visualizes the predictions from the zero-inflated fatality model and the property damage model. This map uses Fishers' classification with three classes for each variable, for a total of nine classes. We use spearmen's rank correlation to compare how the counties most at risk for flood death and property damage compare to high social vulnerability counties identified by the 2006-2010 SoVI index.

\section{Results}

\subsection{Fatalities}

Results from textual analysis of the Storm Events Database indicates that the typical flood fatality involves a drowning incident in a car, commonly by men alone, but sometimes mothers and children, while crossing a river in a rural area of the country. While not all narratives contained information on gender and age of the people who died, more than 50 percent of the cases involve men drowning in cars (Figure 1). 
Machine learning using fatality counts as the response revealed three county-level variables had a relative importance greater than zero (in order of importance): percent rural (85.9\%), percent of that population speaking no English (9.67\%), and percent Asian (4.44\%). These three variables formulate model $5 a$ (Table 3). Using a binary variable for fatalities (e.g. presence or absence of a death in a flood event) as the response (Bernoulli distribution), the machine learning identified ten variables with a relative importance greater than zero (Table 4). These ten variables frame model $5 b$ (Table 3 ).

Regression analysis of fatalities indicates that model fit is lowest for models that only include biophysical variables (Model 2, AIC= 2894). Model fit increases with SoVI is added (Model 3, AIC=2829), but performs better when adding individual social components identified in the literature (Model 4a, AIC=2732) and geographic controls (Model4c, AIC=2696). Models constructed with social factors identified in machine learning do not perform as well as models constructed with theory (Model 5a and Model 5b AIC=2728 and 2744, respectively). Higher flood magnitude is consistently a significant predictor increased death counts across all models $(p<.01)$, while flash floods in particular were not found increase death counts. Residuals were significantly spatial autocorrelated for death model residuals (Moran's I, p<.001). However, methods to implement spatial weights for zero-inflated regression with a negative binomial distribution were not available at the time this paper was written (for a zero-inflated geographically weighted regression with a Poisson distribution, see the lctools package from [119]). Spatial autocorrelation suggests caution in model interpretation, as model fit and coefficient estimates could be overestimated. We only interpret variables as significant that are $<.05$, and not those that are $<.1$, due to potential inflation of coefficient estimates and small standard errors induced by spatial autocorrelation.

Three social variables have significant and positive coefficients across all model formulations: percent rural, percent of the population under 5 years old, and percent of the population over 65 old. These three characteristics were also found in the text mining analysis (Figure 1), providing additional validation. Rural percent of the county population is the strongest predictor of death count across all models $(p<.01)$. Two of the eight regional division variables, both in the Southern US (West South Central and East South Central), have a significant effect in increasing death counts (model $4 c, p<.01, p<.01$, respectively). Counties with high proportions of younger ( $<5$ years) and elderly populations also have increased propensity to flood death $(p<.01)$. Other variables are inconsistent across models. For example, counties with a lower percentage of health insurance coverage for the population are positively correlated with death counts in models $4 a(p<.05)$ and $4 b(p<0.1)$, but when geographic division controls are added, this significant effect disappears. 

Flood Death Related to Vehicles, Drowning, A
and Mobile Homes

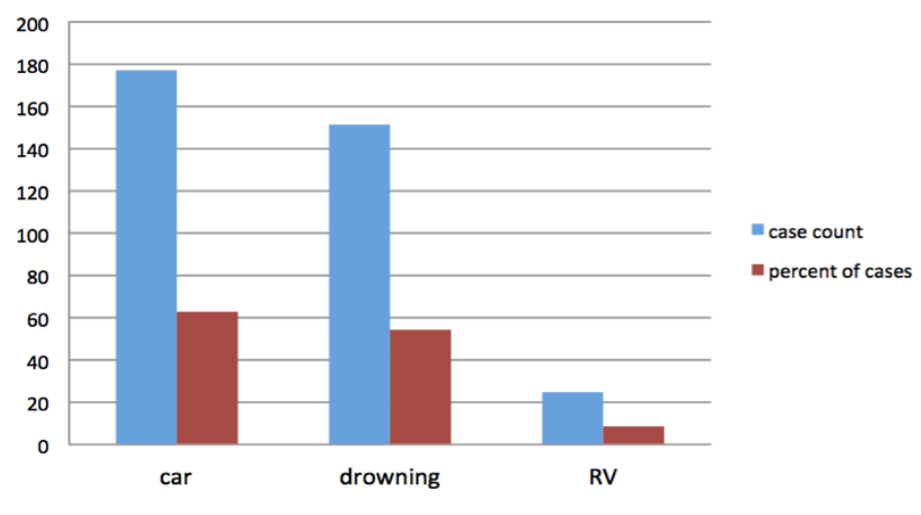

Gender and Demographic Trends in Flood B Deaths

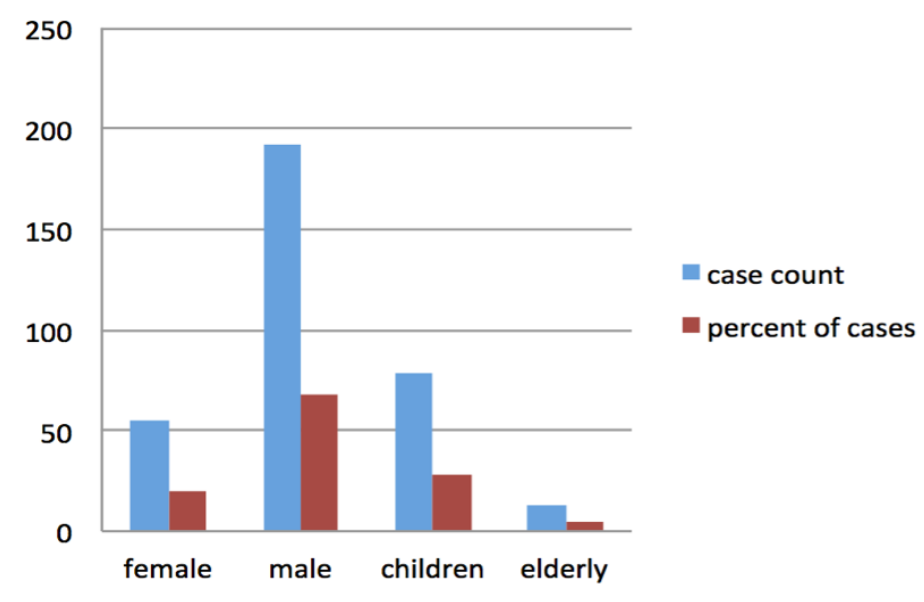

Figure 1. Results of text mining event narratives from flood fatalities data $(n=283)$. A) demographic trends (age and gender) in flood fatalities cases. B) cause of death involving cars, drowning , or RV's/mobile homes.

Table 4: Social variables with non-zero relative importance from machine learning for fatalities and $>1 \%$ importance for property.

\begin{tabular}{|l|r|r|r|}
\hline Variable & $\begin{array}{r}\text { Relative Influence- } \\
\text { Fatalities as Counts }\end{array}$ & $\begin{array}{r}\text { Relative Influence- } \\
\text { Fatalities as Binary }\end{array}$ & $\begin{array}{r}\text { Relative Influence- } \\
\text { In Property Damage } \\
\text { Ratio }\end{array}$ \\
\hline \%MobileHomes & & 37.99 & 0.19 \\
\hline \%Unoccupied & & 16.79 & 1.12 \\
\hline perCapitalncome & & 14.76 & 1.25 \\
\hline \%Rural & 85.89 & 14.01 & 49.28 \\
\hline \%Households200k & & 5.90 & 3.06 \\
\hline peoplePerUnit & & 4.09 & 0 \\
\hline medianRent & & 3.87 & 11.93 \\
\hline
\end{tabular}




\begin{tabular}{|l|r|r|r|}
\hline \%NoCar & & 1.41 & 1.31 \\
\hline \%Hispanic & & 0.76 & 0.54 \\
\hline \%NursingHome & 9.67 & 0.44 & 0.91 \\
\hline \%No English & 4.44 & & 0.48 \\
\hline \%Asian & & & 3.51 \\
\hline \%Hospital & & & 7.76 \\
\hline \%Black & & & 1.93 \\
\hline \%Unemployed & & & 1.81 \\
\hline \%FemaleHeadHouse & & & 1.77 \\
\hline \%under5 & & & 1.56 \\
\hline \%perCapitalncome & & & 1.25 \\
\hline \%Unoccupied & & & \\
\hline
\end{tabular}

* Other variables predicting property ratio with relative importance $>0$ but $<1$ include \%Native American, \%nolnsurance, \%EmployedinServices, \%Underpoverty, \%Female, \%Femaleworkforce, \%Socialsecurity, \%employedinextractive.

Table 5. Fatality model results.

Zero Inflated Fatality Models

Dependent variable:

Death Count

\begin{tabular}{|c|c|c|c|c|c|c|c|}
\hline & \multicolumn{7}{|c|}{ Dependent variable: } \\
\hline & \multicolumn{7}{|c|}{ Death Count } \\
\hline & Biophysical (2) & SoVI (3) & Social(Lit) (4a) & Social(Lit)+reg (4b) & Social(Lit)+div (4c) & Social-ML(count) (5a) & Social-ML(binary) (5b) \\
\hline floodReturnTime & $0.199^{* * *}(0.074)$ & $0.215^{* * *}(0.070)$ & $0.212^{* * *}(0.056)$ & $0.206^{* * *}(0.055)$ & $0.108^{* *}(0.047)$ & $0.114^{* *}(0.049)$ & $0.201^{* * *}(0.055)$ \\
\hline flashFlood & $0.109(0.197)$ & $0.041(0.184)$ & $-0.093(0.164)$ & $-0.137(0.164)$ & $-0.049(0.165)$ & $0.115(0.165)$ & $-0.103(0.164)$ \\
\hline percentImpervious & $-0.541^{* * *}(0.080)$ & $-0.407^{* * *}(0.075)$ & & & & & \\
\hline US_SOVI & & $0.331^{* * *}(0.041)$ & & & & & \\
\hline percentBlack & & & $-0.077(0.104)$ & $-0.191^{*}(0.114)$ & $-0.161(0.117)$ & & \\
\hline percentFemale & & & $-0.039(0.149)$ & $-0.126(0.150)$ & $-0.083(0.155)$ & & \\
\hline percentNoHealthInsurance & & & $0.326^{* *}(0.135)$ & $0.258^{*}(0.140)$ & $0.199(0.146)$ & & \\
\hline percentAsian & & & & & & $-0.149^{*}(0.080)$ & \\
\hline percentNursingHome & & & & & & & $0.296^{* *}(0.118)$ \\
\hline percentRural & & & $0.793^{* * *}(0.127)$ & $0.784^{* * *}(0.133)$ & $0.761^{* * *}(0.128)$ & $1.102^{* * *}(0.093)$ & $0.678^{* * *}(0.147)$ \\
\hline peoplePerUnit & & & & & & & $0.177(0.153)$ \\
\hline percentUnoccupied & & & & & & & $0.311^{* * *}(0.117)$ \\
\hline percentMobileHomes & & & $0.070(0.145)$ & $0.032(0.153)$ & $0.082(0.149)$ & & $0.413^{* * *}(0.125)$ \\
\hline percentUnderPoverty & & & $-0.261(0.207)$ & $-0.204(0.207)$ & $-0.139(0.212)$ & & \\
\hline percentUnder5yo & & & $0.429^{* * *}(0.133)$ & $0.497^{* * *}(0.142)$ & $0.448^{* * *}(0.137)$ & & \\
\hline percentOver65yo & & & $0.452^{* * *}(0.139)$ & $0.555^{* * *}(0.145)$ & $0.510^{* * *}(0.144)$ & & \\
\hline percentNoEnglish & & & $-0.644(0.498)$ & $-0.776(0.511)$ & $-0.992^{*}(0.518)$ & $0.207(0.383)$ & \\
\hline perCapitaIncome & & & & & & & $0.287(0.177)$ \\
\hline percentHispanic & & & & & & & $0.087(0.174)$ \\
\hline percentNoCar & & & $0.145(0.147)$ & $0.225(0.159)$ & $0.235(0.166)$ & & $0.038(0.117)$ \\
\hline percentAmbulatoryDifficulty & & & $0.276^{* *}(0.140)$ & $0.150(0.149)$ & $0.109(0.151)$ & & \\
\hline NE_region & & & & $0.123(0.399)$ & & & \\
\hline S_region & & & & $0.597^{*}(0.306)$ & & & \\
\hline MW_region & & & & $0.015(0.332)$ & & & \\
\hline NE_MA_division & & & & & $0.357(0.314)$ & & \\
\hline S_SA_division & & & & & $0.290(0.313)$ & & \\
\hline S_ESC_division & & & & & $0.838^{* * *}(0.301)$ & & \\
\hline S_WSC_division & & & & & $0.915^{* * *}(0.259)$ & & \\
\hline medianRent & & & & & & & $-0.340^{*}(0.174)$ \\
\hline Constant & $-14.521^{* * *}(0.158)$ & $-14.379^{* * *}(0.146)$ & $-14.507^{* * *}(0.159)$ & $-14.777^{* * *}(0.298)$ & $-14.329^{* * *}(0.235)$ & $-13.829^{* * *}(0.200)$ & $-14.313^{* * *}(0.135)$ \\
\hline Observations & 11,629 & 11,629 & 11,629 & 11,629 & 11,629 & 11,629 & 11,629 \\
\hline Log Likelihood & $-1,440.462$ & $-1,406.797$ & $-1,349.118$ & $-1,345.736$ & $-1,327.129$ & $-1,355.418$ & $-1,357.420$ \\
\hline Akaike Inf. Crit. & $2,894.924$ & $2,829.594$ & $2,732.235$ & $2,731.472$ & $2,696.258$ & $2,728.836$ & $2,744.839$ \\
\hline
\end{tabular}




\subsection{Property Damage}

Property damage models reveal similar trends to fatality models (Table 6). Models using only biophysical variables predict a small amount of variation in property damage ratios (Model 2, $\left.\mathrm{R}^{2}=0.09\right)$. Variation explained increases with models adding the SoVI Index, which is a significant predictor of damage ratios (Model $3, R^{2}=0.13, p<.01$ ). Models with social factors selected from both the literature and machine learning explained more variation compared to SoVI only models (Models $4 a, 4 b$, and $5 c, R^{2}=.20$ for each). The best performing model includes race and poverty interactions and geographic divisions (Model $5 d, R^{2}=.23$ ). Flood magnitude is a significant predictor, and larger floods increase with damage across all models $(p<.01)$. We did not find spatial autocorrelation in residuals for property damage models.

Five social factors significantly increase property damage ratios across all models. Damage is higher in rural counties, in counties with lower median house values, lower housing density (people per home), higher percentage of population below the poverty line, and in counties with lower percentages of Asian populations across all models $(p<.01)$. Counties with higher Native American populations experience higher damage ratios across two models (6a and $6 \mathrm{~b}$, $p<.05)$. An interaction between percent of Native Americans and people below the poverty line is also significant (model $6 \mathrm{~d}, \mathrm{p}<.001$ ). In the best performing model $(6 \mathrm{~d})$ race and class interactions reveal that property damage increases particularly in locations with more poor Black, Hispanic, and Native American populations, but decreases in countries with more poor Asian populations ( $p<.01$ for all interactions). These results suggest that high damage ratios are concentrated in poor communities of color. Geographic location significantly explains property damage in 7 of the 8 census divisions tested. Damage is significantly higher for the West South Central $(p<.01)$, Middle Atlantic $(p<.05)$ and New England $(p<.01)$, the Western Pacific $(p<.01)$, and Western-Central Midwest $(p<.05)$ and lower for the Eastern Central Midwest and South Atlantic division ( $p<.05$ for both). 
Table 6. Property damage model results

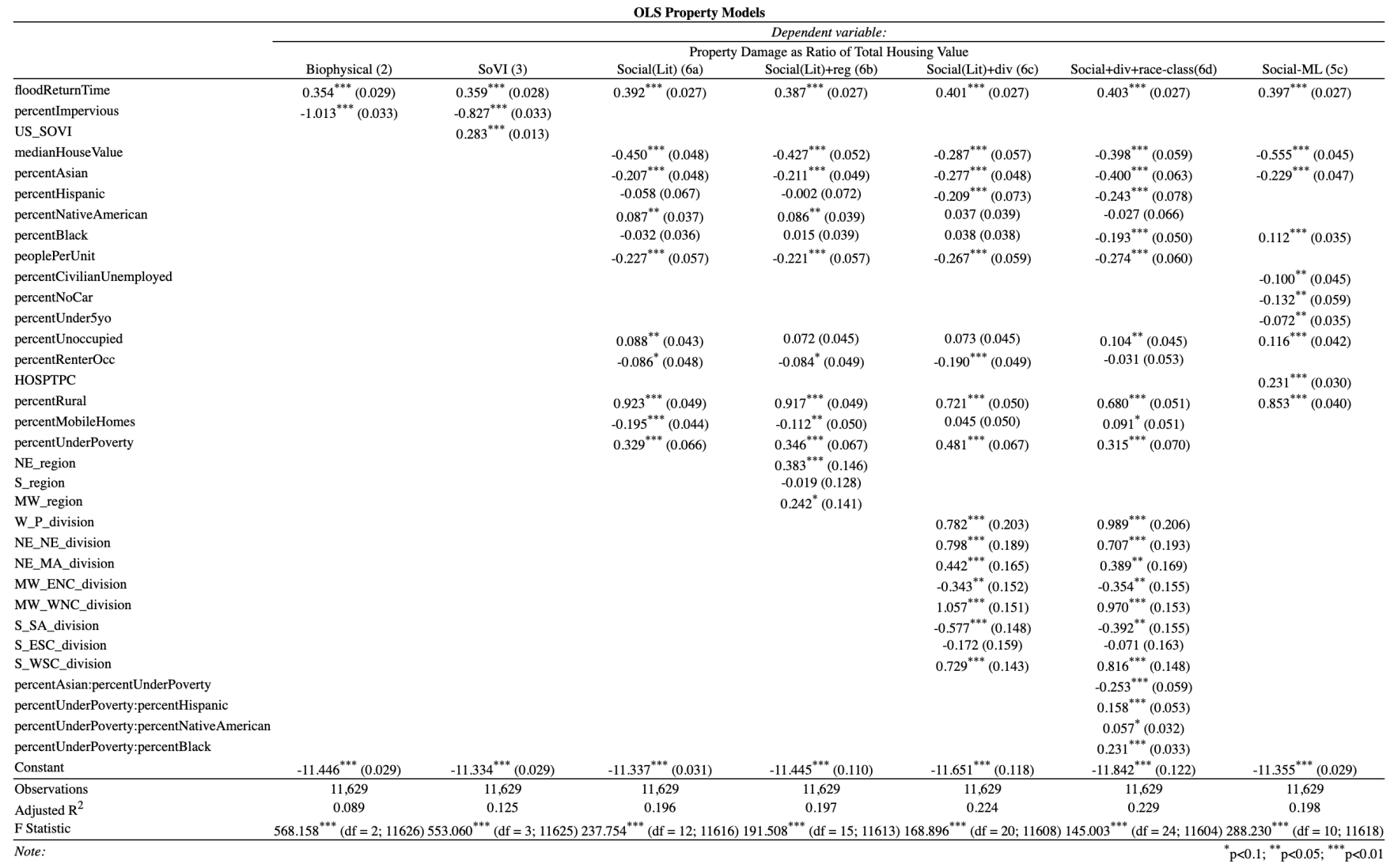

\subsection{Social versus biophysical influence explaining variation in death and damage}

Social factors increase model performance and add significant predictability to flood death (Figure 2A) and damage in the US. Deviance explained from death count models with only biophysical variables (model $2,0.014$ ) increased when adding SoVI (model 3, 0.037) or individual social factors identified in machine learning (model 5a, 0.072) and the literature (model 4a, 0.076 and model 4c, 0.091). Variance explained in property damaged increased from just $9 \%$ in a biophysical model (model 2 ), to over $23 \%$ when social and geographic factors were added to the model (model 6d) (Figure 2B). 

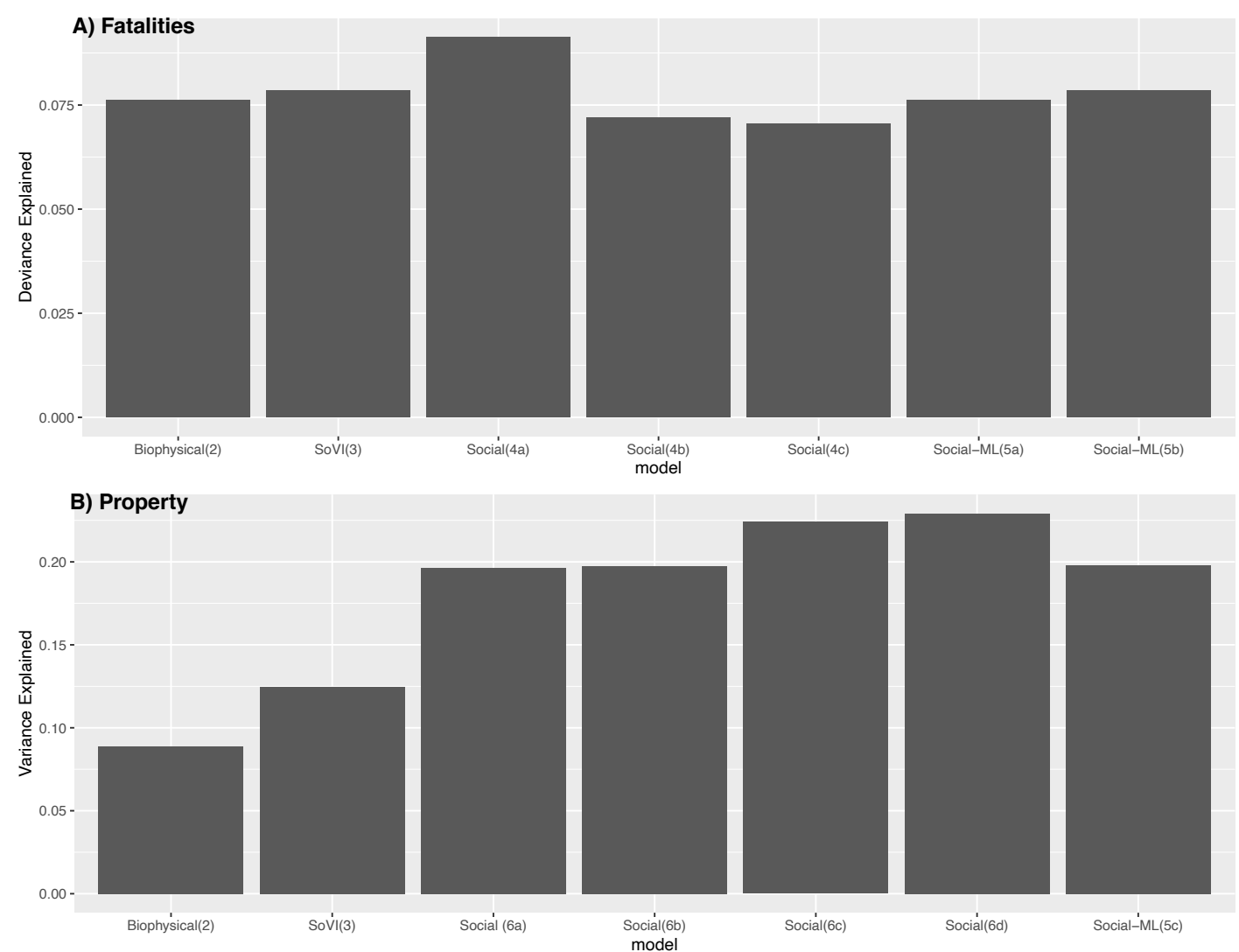

Figure 2. Deviance explained for A) fatality models (difference between each model and a null model in predicting death counts) and $\mathrm{R}^{2}$ values for $\mathrm{B}$ ) property models.

\subsection{Predicted spatial distribution of death and damage in a 500-year flood event}

The best performing model for flood fatalities (Model 4c, social vulnerability variables selected from literature including geographic controls) and damage (Model 6d, social vulnerability variables selected from literature including geographic control) were used to predict death and damage across the USA for a hypothetical 500-year flood (Figure 3). Results show that in a large flood event, property damages occur across a wide portion of the USA, and are highest across the South East, Southwest, Midwest, and in the Northern portion of New England. Deaths are highest in the Appalachian region, and in the South-Central portions of the US and Plains states, and coincide with high property damage ratios. Only in portions of Utah are there regions with predicted higher deaths but not property damage. Counties with predicted higher death and damage are significantly correlated $(r=.79, p<.001)$. Counties with higher predicted damage are more correlated to counties with high SoVI $(r=.63, p<.001)$ than countries with predicted fatalities (Spearman's Rank Correlation $=.42, \mathrm{p}<.001$ ). This suggests SoVI is more predictive of the spatial distribution of counties with higher flood damage relative to local property values than the spatial distribution of flood fatality. The top ten counties for predicted death and damage do not share any counties (Table 7), but three predicted damage top counties also appear with some of the high SoVI counties (Todd and Shannon, SD and Sioux, ND). 


\section{Predicted Death and Damage For a $\mathbf{5 0 0}$ year flood}

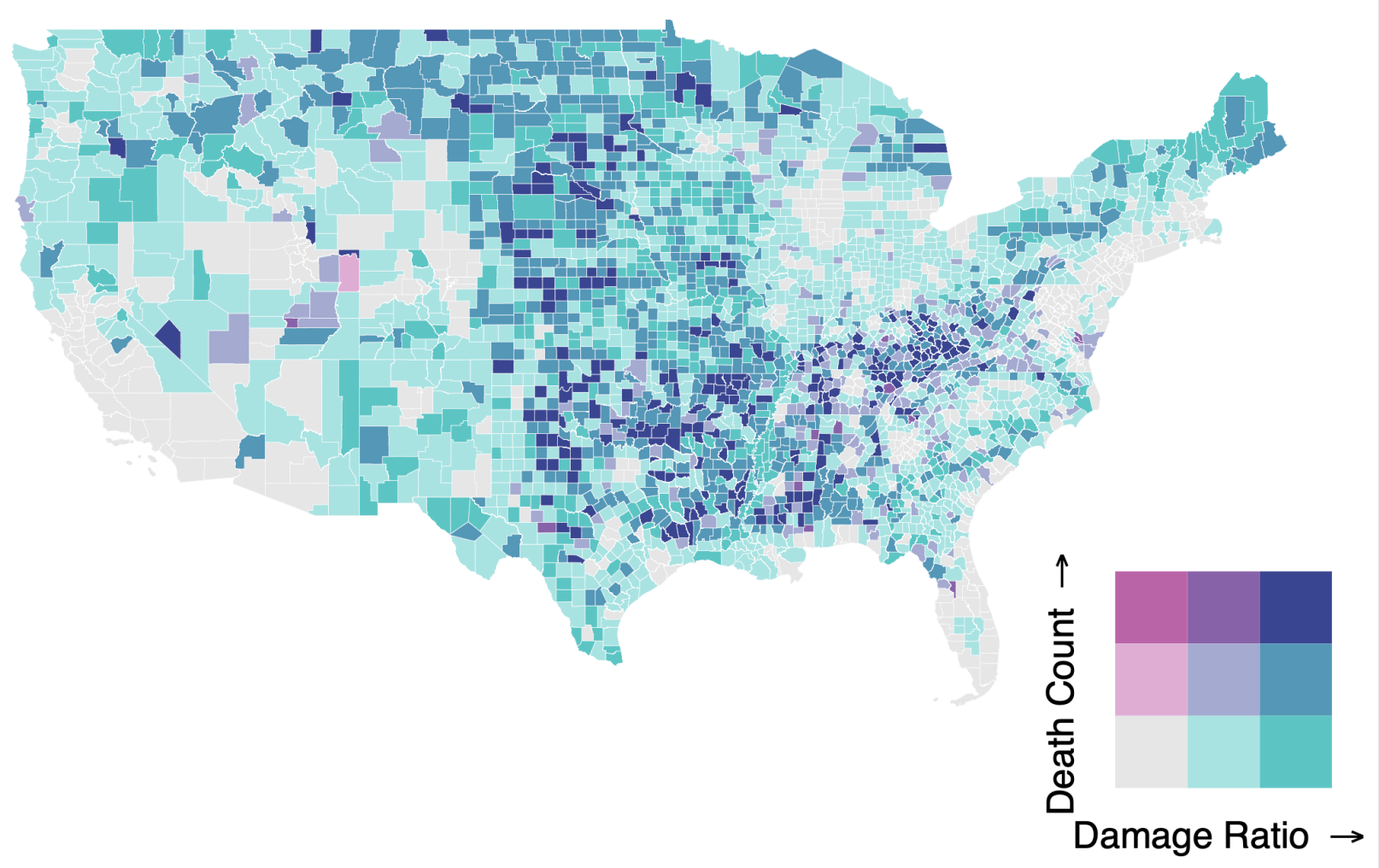

Figure 3. Bivariate choropleth map showing predicted fatalities and property damage

Table 7: Top 10 US counties with highest predicted fatalities and property damage for a 500year flood. SoVI scores (from The Hazards and Vulnerability Institute, 2006-2010 version) reported in percentiles. Higher SoVI is higher social vulnerability.

\begin{tabular}{|l|r|l|l|r|r|r|}
\hline County & Deaths & SoVI & County & Property Damage & County & SoVI \\
\hline Baylor, TX & 4 & 0.90 & Holmes, MS & 0.258 & Buffalo, SD & 0.87 \\
\hline Stone, AR & 4 & 0.88 & Jefferson, MS & 0.181 & Daniels, MT & 0.93 \\
\hline McIntosh, OK & 4 & 0.94 & Hudspeth, TX & 0.144 & Sioux, ND & 0.97 \\
\hline Letcher, KY & 4 & 0.79 & Shannon, SD & 0.099 & Brooks, TX & 1 \\
\hline Motley, TX & 4 & 0.94 & Todd, SD & 0.098 & Bronx, NY & 1 \\
\hline Sabine, LA & 4 & 0.85 & Wilcox, AL & 0.091 & Todd, SD & 0.88 \\
\hline McPherson, NE & 3 & 0.56 & Buffalo, IL & 0.080 & Shannon, SD & 1 \\
\hline Hickman, KY & 3 & 0.83 & Issaquena, MS & 0.064 & Menominee, WI & 0.99 \\
\hline Menard, TX & 3 & 0.99 & Allendale, SC & 0.062 & La Salle, TX & 0.90 \\
\hline Montgomery, AR & 3 & 0.96 & Sioux, ND & 0.059 & Clay, GA & 1 \\
\hline
\end{tabular}




\section{Discussion}

Results provide strong support for empirical evidence and validation that social vulnerability leads to higher death and damage in flood events in the US. In general, we found models including social factors to predict death and damage explain about twice as much variation in flood outcomes as models including only flood magnitude, flood type, and impervious surface. The main driver of outsized death and property damage as a proportion of total property values is rurality, which is related to other specific factors of high social vulnerability. Models predicting damage and death count both improved significantly in variation explained when including SoVI, a composite indicator of social vulnerability. This finding is consistent with previous validation studies, finding SoVI predicts property damage $[21,36]$. Our study is the first validation of SoVI to flood events across the US. However, explained variance of both death and damage models increased even more when selecting individual components of the SoVI as well as other social variables previous research indicated as related to flood death and damage (Figure 2, Table 5). Previous research on Hurricane Sandy likewise found models constructed with specific components of social vulnerability (termed vulnerability profiles, Rufat et al [21]) had higher predictability of distinct flood outcomes than a general index like the SoVI. We found that in addition to general social vulnerability (from the SoVI), rural counties and counties the Central Southwestern US has a higher propensity for loss of both lives and property. However, other specific components of vulnerability are related to distinct death versus property loss outcomes.

\subsection{Flood fatalities}

Consistent with previous literature, model results indicate countries with more elderly and young populations, as well as and rural locations are two factors related to higher flood fatalities. Quantitative and qualitative studies have found very old and very young populations more likely to die in a flood event either from drowning or complications related to medical access post-event $[49,54-57]$. Rural locations also have an older age distribution in the USA[120], although including rurality and percent elderly in a county the same model did not cause multi-collinearity (based on variable inflation coefficient tests). While rurality and age are likely related to higher flood deaths, causation cannot be ascribed from the correlative results presented here.

We found SoVI significantly increased with flood death counts, contrary to a previous study which did not find SoVI a significant factor of flood death across multiple hazards across Southeastern States [36]. Bakkensen et al [36] did not use a direct measure of flood magnitude to control for hazards. Contrary to previous work (e.g. Zahran et al [61]we found neither race nor poverty significantly correlated with flood deaths. Our sample size, however, did not include significant events such as Hurricane Katrina (2005) and Hurricane Audrey (1957), which found Black populations had higher propensity for flood death $[59,60]$. Our nation-wide study found regional patterns of flood death in Appalachia, the Ohio River Valley, and in South Central Texas, consistent with previous studies [53,61]. 


\subsection{Property damage}

Consistent with previous studies, we found SoVI and poverty to be significantly correlated with flood damage $[21,36,121]$. Other studies, such as Yoon et al [121], using absolute property damage across multiple hazard types in coastal areas from 1990-2010, found urban areas and high ratios of female population correlated with property loss. Their results could contradict ours due to differences in spatial extent, temporal extent, and most likely normalization of the dependent variables (our regressions are on property damage ratios, theirs are absolute loss estimates, which one would expect to be very high in urban areas). Significant social factors in the best performing model indicate rural areas and the interaction of race and poverty have the largest influence on property damage. The most striking result from our models was the significant interaction of some races (Black, Native American, and Hispanic) and poverty in predicting property damage. Previous qualitative research has found, for example, that it is not Black communities generally that suffered greatest property losses in Hurricane Katrina, but low income Black communities specifically [76]. Our results indicate the influence poverty-race interactions leading to greater property losses extend beyond Hurricane Katrina and is a generalizable phenomenon across the contiguous validated by empirical data for over 11,000 events. We found the interaction of poverty and Asian population to be negative, suggesting regions with poor Asian communities experience less property loss than other populations. High propensity for property loss in poor communities of color could be due to increased flood exposure (due to limited housing choices and more accessible housing in floodplains), poor housing quality, structural racism (e.g. systematic underinvestment in flood mitigation structures such as levees), or institutional racism and bias (e.g. low flood insurance coverage (7\%) in Native American communities because FEMA was not mapping them, a prerequisite for the National Flood Insurance Program [85]. Investments in flood mitigation infrastructure, improved zoning, opportunities for buyout and relocation [122] and financial support for risk transfer mechanisms such as insurance should be targeted towards poor communities of colorBlack, Hispanic, and Native American specifically- to address this gap.

\subsection{Spatial distribution of death and damage and model limitations}

Model results indicate significant geographic variation in flood death and damage. Figure 3 suggests specific regions susceptible to flood outcomes, and the interaction of death and damage. Previous flood research has found flood exposure trends also exhibit geographic hotspots over the contiguous US [86]. Some of the hotspots of increasing flood exposure, for example in Appalachia and along the Ohio River, are the same regions our model finds coincident high propensity for death and damage in large flood events (Figure 3). Spatial autocorrelation in flood death models suggest validating social vulnerability of flood deaths may require development of geographically weighted zero-inflated regression with negative binomial distributions. Subsequent research could extend this study by developing geographically weighted models to explore how social factors leading at different scales significantly predict death and damage vary across the country. Future work could compare flood damage directly from FEMA public assistance data or insurance claims, to examine if factors identified in this study prediction flood damage ratios differ in homeowner loss specific 
datasets. Vulnerability and resilience to hazards in the US may also change over time [23], and we encourage future studies to empirically validate vulnerability across time to test this hypothesis. The hazard control from flood magnitude from stream gauges are an improvement over past studies which used precipitation [61] or NCEI intensity scores [36]. Direct measures of spatial flood depth per hazard (as used by Rufat et al[21]) for each flood hazard in the Storm Events database would be the preferred control variable, but was unavailable at the time of this study.

An important qualification of our results is that social factors were aggregated at the county level, and variation in flood outcomes at the household level are excluded at this unit of analysis. This means that the relationships described in this study here apply at broad geographic scales, but different relationships may apply at more local scales or at the individual level. Other important components of social vulnerability, including social cohesion, social capital, and risk perception identified in place-based and qualitative studies are difficult to meaningfully measure at county scales, but their validation across large geospatial scales remains important.

\subsection{Further research needs}

This study adds to a small but growing number of social vulnerability validation studies, further identifying specific social factors that lead to higher propensity for loss in hazard events. While we found indices like SoVI to be correlated with flood death and damage outcomes at the county scale, digging deeper into specific social factors revealed that some, but not all, SoVI components are significant factors. Recent studies [21] have suggested validating constructed vulnerability profiles of related social factors as a way forward. We confirm their recommendation that more social vulnerability validation is needed across a wider array of spatial and temporal scales, since the scale and accuracy of both the flood hazard and social vulnerability variables critically affect findings [123]. Socioeconomic and demographic factors at the household, community, and larger scales need to be tested in additional multi-scale validation studies to understand how gender, for example, may increase risk of death in a flood at a household but not at county scales. Social vulnerability validation across hazards is necessary in order to direct policy interventions to address floods, heat waves, and tornados to the populations and places that need them most. Knowing, for example, that people above age 65 are more at risk of death from flooding may enable policy makers to identify those populations in advance for early evacuation before floods occur or to reinforce flood protections near long term care facilities. SoVI scores may serve as a general guide of vulnerability, but hazard specific models are likely to yield more specific and useful policy recommendations. Finally, social vulnerability validation across phases of the disaster cycle is needed. For example, while populations with young age distributions may have greater propensity for flood death in a hazard event, they might also have higher rates of recovery if children are more psychologically resilient to hazards in the recovery phase [57].

\section{Conclusion}


Overall, the methods explored in this study indicate that the hazards of-place model [5], which has inspired decades of research into the social conditions that influence the vulnerability of people-in-place to specific hazards, can be extended by building empirically validated social vulnerability models of hazard specific disaster outcomes. In this case, sensitivity to flood events regarding mortality and economic damage are validated for the 48 contiguous United States. The results support some of the vulnerability factors identified in past research, including county-level measures of racial/ethnic composition, poverty, the elderly and young population, and rural location. Others factors identified in past research were not related to flood impacts in our analysis, including gender and mobile home prevalence.

The data-driven validation method presented here to assess vulnerability could also be used to validate commonly used indicators of resilience or coping capacity, which also suffer from inadequate validation. Validation not only identifies factors to which disaster mitigation policies should pay attention, but also allow for a more systematic study of changes in social vulnerability over space and time. A place based yet broad-scale understanding of validated factors leading to social vulnerability is crucial as urbanization and climate change influence and change the rate, intensity, and location of hazards across the globe.

\section{Acknowledgments}

Thanks to the Cloud to Street team and B.L. Turner II for comments on earlier version of this manuscript.

Conflicts of Interest

Author declare no conflict of interest.

\section{References}

1. Burton, I. The environment as hazard; Guilford Press, 1993; ISBN 0-89862-159-3.

2. Kates, R.W.; Burton, I. Gilbert F. White, 1911-2006 Local Legacies, National Achievements, and Global Visions. Ann. Assoc. Am. Geogr. 2008, 98, 479-486, doi:10.1080/00045600801925656.

3. Watts, M. On the poverty of theory: natural hazards research in context. In Interpretations of calamity from the viewpoint of human ecology; Hewitt, K., Ed.; Allen \& Unwin, Boston MA, 1983; pp. 231-262.

4. Blaikie, P.; Terry, C.; Ian, D.; Ben, W. At Risk: Natural Hazards, People's Vulnerability, and Disasters. Hum. Ecol. 1996, 24, 141-145, doi:10.4324/9780203428764.

5. Cutter, S.L. Vulnerability to environmental hazards. Prog. Hum. Geogr. 1996, 20, 529539, doi:10.1177/030913259602000407.

6. Turner, B.L.; Kasperson, R.E.; Matson, P. a; McCarthy, J.J.; Corell, R.W.; Christensen, L.; Eckley, N.; Kasperson, J.X.; Luers, A.; Martello, M.L.; et al. A framework for vulnerability analysis in sustainability science. Proc. Natl. Acad. Sci. U. S. A. 2003, 100, 8074-8079, doi:10.1073/pnas.1231335100.

7. White, G.F. Natural hazards, local, national, global; Oxford University Press, 1974; 
8. Adger, W.N. Vulnerability. Glob. Environ. Change 2006, 16, 268-281.

9. Birkmann, J.; Wisner, B. Measuring the unmeasurable: the challenge of vulnerability; UNU-EHS, 2006; ISBN 3-9810582-6-7.

10. Eakin, H.; Luers, A.L. Assessing the Vulnerability of Social-Environmental Systems. Annu. Rev. Environ. Resour. 2006, 31, 365-394, doi:10.1146/annurev.energy.30.050504.144352.

11. Eriksen, S.H.; Kelly, P.M. Developing Credible Vulnerability Indicators for Climate Adaptation Policy Assessment. Mitig. Adapt. Strateg. Glob. Change 2007, 12, 495-524, doi:10.1007/s11027-006-3460-6.

12. IPCC Climate Change 2014-Impacts, Adaptation and Vulnerability: Regional Aspects; Cambridge University Press, 2014;

13. Mustafa, D. The Production of an Urban Hazardscape in Pakistan: Modernity, Vulnerability, and the Range of Choice. Ann. Assoc. Am. Geogr. 2005, 95, 566-586, doi:10.1111/j.1467-8306.2005.00475.x.

14. Turner, B.L.; Matson, P. a; McCarthy, J.J.; Corell, R.W.; Christensen, L.; Eckley, N.; Hovelsrud-Broda, G.K.; Kasperson, J.X.; Kasperson, R.E.; Luers, A.; et al. Illustrating the coupled human-environment system for vulnerability analysis: three case studies. Proc. Natl. Acad. Sci. U. S. A. 2003, 100, 8080-8085, doi:10.1073/pnas.1231334100.

15. Schoon, M.; Fabricius, C.; Anderies, J.M.; Nelson, M. Synthesis: vulnerability, traps, and transformations-long-term perspectives from archaeology. Ecol. Soc. 2011, 16, 24.

16. Yoon, D.K. Assessment of social vulnerability to natural disasters: a comparative study. Nat. Hazards 2012, 63, 823-843, doi:10.1007/s11069-012-0189-2.

17. Cutter, S.L.; Boruff, B.J.; Shirley, W.L. Social vulnerability to environmental hazards. Soc. Sci. Q. 2003, 84, 242-261.

18. Federal Emergency Management Agency National Risk Index Available online: https://nationalriskindex-test.fema.gov/.

19. de Sherbinin, A.; Apotsos, A.; Chevrier, J. Mapping the future: policy applications of climate vulnerability mapping in West Africa. Geogr. J. 2017, 183, 414-425.

20. Tate, E. Social vulnerability indices: a comparative assessment using uncertainty and sensitivity analysis. Nat. Hazards 2012, 63, 325-347, doi:10.1007/s11069-012-0152-2.

21. Rufat, S.; Tate, E.; Emrich, C.T.; Antolini, F. How Valid Are Social Vulnerability Models? Ann. Am. Assoc. Geogr. 2019, 109, 1131-1153, doi:10.1080/24694452.2018.1535887.

22. de Sherbinin, A.; Bukvic, A.; Rohat, G.; Gall, M.; McCusker, B.; Preston, B.; Apotsos, A.; Fish, C.; Kienberger, S.; Muhonda, P.; et al. Climate vulnerability mapping: A systematic review and future prospects. Wiley Interdiscip. Rev. Clim. Change 2019, doi:10.1002/wcc.600.

23. Cutter, S.L.; Finch, C. Temporal and spatial changes in social vulnerability to natural hazards. Proc. Natl. Acad. Sci. U. S. A. 2008, 105, 2301-6, doi:10.1073/pnas.0710375105.

24. Spielman, S.E.; Tuccillo, J.; Folch, D.C.; Schweikert, A.; Davies, R.; Wood, N.; Tate, E. Evaluating social vulnerability indicators: criteria and their application to the Social Vulnerability Index. Nat. Hazards 2020, 100, 417-436, doi:10.1007/s11069-019-03820-z.

25. Adger, W.N. Social and ecological resilience: are they related? Prog. Hum. Geogr. 2000, 24, 347-364, doi:10.1191/030913200701540465. 
26. Adger, W.N.; Huq, S.; Brown, K.; Conway, D.; Hulme, M. Adaptation to climate change in the developing world. Prog. Dev. Stud. 2003, 3, 179-195, doi:10.1191/1464993403ps060oa.

27. Denevan, W.M. Adaptation, variation, and cultural geography. Prof. Geogr. 1983, 35, 399-407, doi:10.1111/j.0033-0124.1983.00399.x.

28. Eakin, $\mathrm{H}$. The 'turn to capacity'in vulnerability research. In Applied Studies in Climate Adaptation; Palutikof, J.P., Boulter, S.L., Barnett, J., Rissik, D., Eds.; John Wiley \& Sons Ltd, 2014; pp. 225-230.

29. Holling, C.S. Understanding the complexity of economic, ecological, and social systems. Ecosystems 2001, 4, 390-405, doi:10.1007/s10021-001-0101-5.

30. Kates, R.W.; Travis, W.R.; Wilbanks, T.J. Transformational adaptation when incremental adaptations to climate change are insufficient. Proc. Natl. Acad. Sci. 2012, 109, 71567161, doi:10.1073/pnas.1115521109.

31. Turner, B.L. Vulnerability and resilience: Coalescing or paralleling approaches for sustainability science? Glob. Environ. Change 2010, 20, 570-576, doi:10.1016/j.gloenvcha.2010.07.003.

32. Wise, R.M.; Fazey, I.; Stafford Smith, M.; Park, S.E.; Eakin, H.C.; Archer Van Garderen, E.R.M.; Campbell, B. Reconceptualising adaptation to climate change as part of pathways of change and response. Glob. Environ. Change 2014, 28, 325-336, doi:10.1016/j.gloenvcha.2013.12.002.

33. Lutz, W.; Muttarak, R.; Striessnig, E. Universal education is key to enhanced climate adaptation. Science 2014, 346, 1061-1062, doi:10.1126/science.1257975.

34. Cutter, S.L.; Ahearn, J.A.; Amadei, B.; Crawford, P.; Eide, E.A.; Galloway, G.E.; Goodchild, M.F.; Kunreuther, H.C.; Li-Vollmer, M.; Schoch-Spana, M.; et al. Disaster resilience: A national imperative. Environ. Sci. Policy Sustain. Dev. 2013, 55, 25-29.

35. Luers, A.L. The surface of vulnerability: An analytical framework for examining environmental change. Glob. Environ. Change Part A 2005, 15, 214-223.

36. Bakkensen, L.A.; Fox-Lent, C.; Read, L.K.; Linkov, I. Validating Resilience and Vulnerability Indices in the Context of Natural Disasters: Validating Resilience and Vulnerability Indices. Risk Anal. 2017, 37, 982-1004, doi:10.1111/risa.12677.

37. Jongman, B.; Hochrainer-stigler, S.; Feyen, L.; Aerts, J.C.J.H.; Mechler, R.; Botzen, W.J.W.; Bouwer, L.M.; Pflug, G.; Rojas, R.; Ward, P.J. Increasing stress on disaster-risk finance due to large floods. Nat. Clim. Change 2014, 4, 1-5, doi:10.1038/NCLIMATE2124.

38. Jongman, B.; Ward, P.J.; Aerts, J.C.J.H. Global exposure to river and coastal flooding : Long term trends and changes. Glob. Environ. Change 2012, 22, 823-835, doi:10.1016/j.gloenvcha.2012.07.004.

39. Ward, P.J.; Jongman, B.; Weiland, F.S.; Bouwman, A.; van Beek, R.; Bierkens, M.F.P.; Ligtvoet, W.; Winsemius, H.C. Assessing flood risk at the global scale: Model setup, results, and sensitivity. Env. Res Lett 2013, 8, 44019, doi:10.1088/17489326/8/4/044019.

40. Winsemius, H.C.; Van Beek, L.P.H.; Jongman, B.; Ward, P.J.; Bouwman, a. A framework for global river flood risk assessments. Hydrol. Earth Syst. Sci. 2013, 17, 1871-1892, doi:10.5194/hess-17-1871-2013. 
41. Smith, A.; Bates, P.D.; Wing, O.; Sampson, C.; Quinn, N.; Neal, J. New estimates of flood exposure in developing countries using high-resolution population data. Nat. Commun. 2019, 10, doi:10.1038/s41467-019-09282-y.

42. Wing, O.E.J.; Bates, P.D.; Smith, A.M.; Sampson, C.C.; Johnson, K.A.; Fargione, J.; Morefield, P. Estimates of present and future flood risk in the conterminous United States. Environ. Res. Lett. 2018, 13, 034023, doi:10.1088/1748-9326/aaac65.

43. Mustafa, D. Reinforcing vulnerability? Disaster relief, recovery, and response to the 2001 flood in Rawalpindi, Pakistan. Glob. Environ. Change Part B Environ. Hazards 2003, 5, 7182.

44. Rufat, S.; Tate, E.; Burton, C.G.; Maroof, A.S. Social vulnerability to floods: Review of case studies and implications for measurement. Int. J. Disaster Risk Reduct. 2015, 14, 470486, doi:10.1016/j.ijdrr.2015.09.013.

45. Azar, D.; Rain, D. Identifying population vulnerable to hydrological hazards in San Juan, Puerto Rico. GeoJournal 2007, 69, 23-43, doi:10.1007/s10708-007-9106-8.

46. Fekete, A. Validation of a social vulnerability index in context to river-floods in Germany. Nat. Hazards Earth Syst. Sci. 2009, 9, 393-403.

47. Finch, C.; Emrich, C.T.; Cutter, S.L. Disaster disparities and differential recovery in New Orleans. Popul. Environ. 2010, 31, 179-202, doi:10.1007/s11111-009-0099-8.

48. Bashier Abbas, H.; K. Routray, J. Vulnerability to flood-induced public health risks in Sudan. Disaster Prev. Manag. Int. J. 2014, 23, 395-419, doi:10.1108/DPM-07-2013-0112.

49. Alderman, K.; Turner, L.R.; Tong, S. Floods and human health: A systematic review. Environ. Int. 2012, 47, 37-47, doi:10.1016/j.envint.2012.06.003.

50. Fothergill, A. Gender, risk, and disaster. Int. J. Mass Emergencies Disasters 1996, 14, 3356.

51. Neumayer, E.; Plümper, T. The Gendered Nature of Natural Disasters: The Impact of Catastrophic Events on the Gender Gap in Life Expectancy, 1981-2002. Ann. Assoc. Am. Geogr. 2007, 97, 551-566, doi:10.1111/j.1467-8306.2007.00563.x.

52. Chowdhury, A.M.R.; Bhuyia, A.U.; Choudhury, A.Y.; Sen, R. The Bangladesh cyclone of 1991: why so many people died. Disasters 1993, 17, 291-304.

53. Ashley, S.T.; Ashley, W.S. Flood Fatalities in the United States. J. Appl. Meteorol. Climatol. 2008, 47, 805-818, doi:10.1175/2007JAMC1611.1.

54. Jonkman, S.N.; Kelman, I. An analysis of the causes and circumstances of flood disaster deaths. Disasters 2005, 29, 75-97.

55. Lowe, D.; Ebi, K.; Forsberg, B. Factors Increasing Vulnerability to Health Effects before, during and after Floods. Int. J. Environ. Res. Public. Health 2013, 10, 7015-7067, doi:10.3390/ijerph10127015.

56. Ngo, E.B. When disasters and age collide: Reviewing vulnerability of the elderly. Nat. Hazards Rev. 2001, 2, 80-89.

57. Peek, L. Children and disasters: Understanding vulnerability, developing capacities, and promoting resilience-An introduction. Child. Youth Environ. 2008, 18, 1-29.

58. Fothergill, A.; Maestas, E.G.; Darlington, J.D. Race, ethnicity and disasters in the United States: A review of the literature. Disasters 1999, 23, 156-173.

59. Sharkey, P. Survival and Death in New Orleans: An Empirical Look at the Human Impact of Katrina. J. Black Stud. 2007, 37, 482-501, doi:10.1177/0021934706296188. 
60. Brunkard, J.; Namulanda, G.; Ratard, R. Hurricane Katrina Deaths, Louisiana, 2005. Disaster Med. Public Health Prep. 2008, 2, 215-223, doi:10.1097/DMP.0b013e31818aaf55.

61. Zahran, S.; Brody, S.D.; Peacock, W.G.; Vedlitz, A.; Grover, H. Social vulnerability and the natural and built environment: a model of flood casualties in Texas. Disasters 2008, 32, 537-560, doi:10.1111/j.1467-7717.2008.01054.x.

62. Rivera, J.D.; Miller, D.S. Continually Neglected: Situating Natural Disasters in the African American Experience. J. Black Stud. 2007, 37, 502-522, doi:10.1177/0021934706296190.

63. Jongman, B.; Winsemius, H.C.; Aerts, J.C.J.H.; Coughlan de Perez, E.; van Aalst, M.K.; Kron, W.; Ward, P.J. Declining vulnerability to river floods and the global benefits of adaptation. Proc. Natl. Acad. Sci. 2015, 201414439, doi:10.1073/pnas.1414439112.

64. Di Baldassarre, G.; Montanari, A.; Lins, H.; Koutsoyiannis, D.; Brandimarte, L.; Blöschl, G. Flood fatalities in Africa: From diagnosis to mitigation: FLOOD FATALITIES IN AFRICA. Geophys. Res. Lett. 2010, 37, n/a-n/a, doi:10.1029/2010GL045467.

65. Formetta, G.; Feyen, L. Empirical evidence of declining global vulnerability to climaterelated hazards. Glob. Environ. Change 2019, 57, 101920, doi:10.1016/j.gloenvcha.2019.05.004.

66. Federal Interagency Committee on Emergency Medical Services 2011 National EMS Assessment; National Highway Traffic Safety Administration, DOT HS, 2011; p. 538;.

67. Minge, E.D.; National Cooperative Highway Research Program; National Cooperative Highway Research Program Synthesis Program; Transportation Research Board; National Academies of Sciences, Engineering, and Medicine Emergency Medical Services Response to Motor Vehicle Crashes in Rural Areas; Transportation Research Board: Washington, D.C., 2013; ISBN 978-0-309-27104-2.

68. Cutter, S.L.; Ash, K.D.; Emrich, C.T. Urban-Rural Differences in Disaster Resilience. Ann. Am. Assoc. Geogr. 2016, 1-17, doi:10.1080/24694452.2016.1194740.

69. Lam, N.S.N.; Arenas, H.; Pace, K.; LeSage, J.; Campanella, R. Predictors of Business Return in New Orleans after Hurricane Katrina. PLOS ONE 2012, 7, e47935, doi:10.1371/journal.pone.0047935.

70. Zhang, Y.; Lindell, M.K.; Prater, C.S. Vulnerability of community businesses to environmental disasters. Disasters 2009, 33, 38-57, doi:10.1111/j.1467-

7717.2008.01061.x.

71. Fothergill, A.; Peek, L.A. Poverty and disasters in the United States: A review of recent sociological findings. Nat. Hazards 2004, 32, 89-110.

72. Chinh, D.; Gain, A.; Dung, N.; Haase, D.; Kreibich, H. Multi-Variate Analyses of Flood Loss in Can Tho City, Mekong Delta. Water 2015, 8, 6, doi:10.3390/w8010006.

73. Kelman, I.; Spence, R. A limit analysis of unreinforced masonry failing under flood water pressure. Mason. Int. 2003, 16, 51-61.

74. Norris, F.H.; Smith, T.; Kaniasty, K. Revisiting the experience-behavior hypothesis: the effects of hurricane Hugo on hazard preparedness and other self-protective acts. Basic Appl. Soc. Psychol. 1999, 21, 37-47.

75. Peacock, W.G.; Girard, C. Ethnic and racial inequalities in hurricane damage and insurance settlements. Hurric. Andrew Ethn. Gend. Sociol. Disasters 1997, 171-190. 
76. Elliott, J.R.; Pais, J. Race, class, and Hurricane Katrina: Social differences in human responses to disaster. Soc. Sci. Res. 2006, 35, 295-321, doi:10.1016/j.ssresearch.2006.02.003.

77. Działek, J.; Biernacki, W.; Bokwa, A. Challenges to social capacity building in floodaffected areas of southern Poland. Nat. Hazards Earth Syst. Sci. 2013, 13, 2555-2566, doi:10.5194/nhess-13-2555-2013.

78. Khunwishit, S.; McEntire, D.A. Testing Social Vulnerability Theory: A Quantitative Study of Hurricane Katrina's Perceived Impact on Residents living in FEMA Designated Disaster Areas. J. Homel. Secur. Emerg. Manag. 2012, 9, doi:10.1515/1547-7355.1950.

79. Kamel, N. Social Marginalisation, Federal Assistance and Repopulation Patterns in the New Orleans Metropolitan Area following Hurricane Katrina. Urban Stud. 2012, 49, 32113231, doi:10.1177/0042098011433490.

80. Atreya, A.; Ferreira, S.; Michel-Kerjan, E. What drives households to buy flood insurance? New evidence from Georgia. Ecol. Econ. 2015, 117, 153-161, doi:10.1016/j.ecolecon.2015.06.024.

81. Fothergill, A. Heads above water: gender, class, and family in the grand forks flood; SUNY Press, 2012; ISBN 0-7914-8472-6.

82. American Society of Civil Engineers 2012 REPORT CARD FOR TEXAS' INFRASTRUCTURE; 2012;

83. American Society of Civil Engineers Flood Control in New Mexico; 2005;

84. National Research Council Dam and levee safety and community resilience: $A$ vision for future practice; National Academies Press, 2012;

85. Government Accounting Office (GAO) Flood Insurance: Participation of Indian Tribes in Federal and Private Programs; 2012;

86. Qiang, Y.; Lam, N.S.N.; Cai, H.; Zou, L. Changes in Exposure to Flood Hazards in the United States. Ann. Am. Assoc. Geogr. 2017, 107, 1332-1350, doi:10.1080/24694452.2017.1320214.

87. Koks, E.E.; Jongman, B.; Husby, T.G.; Botzen, W.J.W. Combining hazard, exposure and social vulnerability to provide lessons for flood risk management. Environ. Sci. Policy 2015, 47, 42-52, doi:10.1016/j.envsci.2014.10.013.

88. Tate, E. Uncertainty Analysis for a Social Vulnerability Index. Ann. Assoc. Am. Geogr. 2013, 103, 526-543, doi:10.1080/00045608.2012.700616.

89. Flanagan, B.E.; Gregory, E.W.; Hallisey, E.J.; Heitgerd, J.L.; Lewis, B. A Social Vulnerability Index for Disaster Management. J. Homel. Secur. Emerg. Manag. 2011, 8, doi:10.2202/1547-7355.1792.

90. Cutter, S.L.; Emrich, C.T. Social Vulnerability Index (SoVI $\left.{ }^{\circledR}\right)$ : Methodology and Limitations; Accessed 27-7-2017, Retrieved from https://data. femadata. com, 2017;

91. Peacock, W.G.; Brody, S.D.; Seitz, W.A.; Merrell, W.J.; Vedlitz, A.; Zahran, S.; Harriss, R.C.; Stickney, R. Advancing resilience of coastal localities: Developing, implementing, and sustaining the use of coastal resilience indicators: A final report. Hazard Reduct. Recovery Cent. 2010, 1-148.

92. Foster, K.A. In search of regional resilience. Urban Reg. Policy Its Eff. Build. Resilient Reg. 2012, 4, 24-59. 
93. Liu, D.; Li, Y. Social vulnerability of rural households to flood hazards in western mountainous regions of Henan province, China. Nat. Hazards Earth Syst. Sci. 2016, 16, 1123-1134, doi:10.5194/nhess-16-1123-2016.

94. Oulahen, G.; Mortsch, L.; Tang, K.; Harford, D. Unequal Vulnerability to Flood Hazards: "Ground Truthing" a Social Vulnerability Index of Five Municipalities in Metro Vancouver, Canada. Ann. Assoc. Am. Geogr. 2015, 105, 473-495, doi:10.1080/00045608.2015.1012634.

95. Füssel, H.-M. Vulnerability: A generally applicable conceptual framework for climate change research. Glob. Environ. Change 2007, 17, 155-167.

96. Chen, C.; Noble, I.; Hellmann, J.; Coffee, J.; Murillo, M.; Chawla, N. University of Notre Dame Global Adaptation Index; Notre Dame, 2015;

97. Soares, M.B.; Gagnon, A.S.; Doherty, R.M. Conceptual elements of climate change vulnerability assessments: a review. Int. J. Clim. Change Strateg. Manag. 2012.

98. Reckien, D.; Lwasa, S.; Satterthwaite, D.; McEvoy, D.; Creutzig, F.; Montgomery, M.; Schensul, D.; Balk, D.; Khan, I. Equity, environmental justice, and urban climate change. Clim. Change Cities Second Assess. Rep. Urban Clim. Change Res. Netw. 2018, 173-224.

99. Hinkel, J. "Indicators of vulnerability and adaptive capacity": Towards a clarification of the science-policy interface. Glob. Environ. Change 2011, 21, 198-208, doi:10.1016/j.gloenvcha.2010.08.002.

100. Mechler, R.; Bouwer, L.M.; Schinko, T.; Surminski, S.; Linnerooth-Bayer, J. Loss and damage from climate change; Springer Nature, 2019;

101. CEMHS The Spatial Hazard Events and Losses Database for the United States Version 14.1 2019.

102. Downton, M.W.; Pielke, R.A. How Accurate are Disaster Loss Data? The Case of U.S. Flood Damage. Nat. Hazards 2005, 35, 211-228, doi:10.1007/s11069-004-4808-4.

103. Wing, O.E.J.; Pinter, N.; Bates, P.D.; Kousky, C. New insights into US flood vulnerability revealed from flood insurance big data. Nat. Commun. 2020, 11, 1444, doi:10.1038/s41467-020-15264-2.

104. FEMA Public Assistance Funded Projects Detail; FEMA, 2017;

105. Simley, J.D.; Carswell Jr, W.J. The National Map-Hydrography: US Geological Survey Fact Sheet 2009-3054. US Geol. Surv. Natl. Cent. Rest. VA 2009.

106. Ries III, K.G.; Guthrie, J.D.; Rea, A.H.; Steeves, P.A.; Stewart, D.W. StreamStats: a water resources web application. US Geol. Surv. Fact Sheet 2008, 3067.

107. Brody, S.D.; Zahran, S.; Highfield, W.E.; Grover, H.; Vedlitz, A. Identifying the impact of the built environment on flood damage in Texas. Disasters 2008, 32, 1-18.

108. Homer, C.G.; Dewitz, J.A.; Yang, L.; Jin, S.; Danielson, P.; Xian, G.; Coulston, J.; Herold, N.D.; Wickham, J.D.; Megown, K. Completion of the 2011 National Land Cover Database for the conterminous United States-Representing a decade of land cover change information. Photogramm Eng Remote Sens 2015, 81, 345-354.

109. Hilbe, J.M.; Robinson, J.O. msme: Functions and Datasets for "Methods of Statistical Model Estimation; 2018;

110. Venables, W.N.; Ripley, B.D. Modern Applied Statistics with S; Fourth.; Springer: New York, 2002; 
111. Zeileis, A.; Kleiber, C.; Jackman, S. Regression models for count data in R. J. Stat. Softw. 2008, 27, 1-25.

112. Bates, D.; Mächler, M.; Bolker, B.; Walker, S. Fitting linear mixed-effects models using Ime4. ArXiv Prepr. ArXiv14065823 2014.

113. Burnham, K.P.; Anderson, D.R. Multimodel Inference: Understanding AIC and BIC in Model Selection. Sociol. Methods Res. 2004, 33, 261-304, doi:10.1177/0049124104268644.

114. Zuur, A.F.; leno, E.N.; Walker, N.; Saveliev, A.A.; Smith, G.M. Mixed effects models and extensions in ecology with R; Statistics for Biology and Health; Springer New York: New York, NY, 2009; ISBN 978-0-387-87457-9.

115. Bivand, R.S.; Wong, D.W. Comparing implementations of global and local indicators of spatial association. Test 2018, 27, 716-748.

116. Reckien, D. What is in an index? Construction method, data metric, and weighting scheme determine the outcome of composite social vulnerability indices in New York City. Reg. Environ. Change 2018, 18, 1439-1451, doi:10.1007/s10113-017-1273-7.

117. Ridgeway, G. gbm: Generalized Boosted Regression Models; 2015;

118. Fox, J.; Weisberg, S. An $R$ companion to applied regression; Sage publications, 2018; ISBN 1-5443-3648-9.

119. Kalogirou, S. Destination Choice of Athenians: An Application of Geographically Weighted Versions of Standard and Zero Inflated P oisson Spatial Interaction Models. Geogr. Anal. 2016, 48, 191-230.

120. CIESEN Elderly Population, Percentage of people who are age 65 and older 2000.

121. Yoon, D.K. Assessment of social vulnerability to natural disasters: a comparative study. Nat. Hazards 2012, 63, 823-843, doi:10.1007/s11069-012-0189-2.

122. Tate, E.; Strong, A.; Kraus, T.; Xiong, H. Flood recovery and property acquisition in Cedar Rapids, lowa. Nat. Hazards 2016, 80, 2055-2079, doi:10.1007/s11069-015-2060-8.

123. de Sherbinin, A.; Bardy, G. Social vulnerability to floods in two coastal megacities: New York City and Mumbai. Vienna Yearb. Popul. Res. 2016, 1, 131-165, doi:10.1553/populationyearbook2015s131. 